\title{
Biofuels
}

\section{Biogas Production Potential of Co-digested Food Waste and Water Hyacinth common to the Niger Delta \\ --Manuscript Draft--}

\begin{tabular}{|c|c|}
\hline Full Title: & $\begin{array}{l}\text { Biogas Production Potential of Co-digested Food Waste and Water Hyacinth common } \\
\text { to the Niger Delta }\end{array}$ \\
\hline Manuscript Number: & TBFU - 2017- 0108R1 \\
\hline Article Type: & Original Article \\
\hline Keywords: & Anaerobic Digestion; Biogas; Food Waste; Niger Delta; Water Hyacinth \\
\hline Abstract: & $\begin{array}{l}\text { Yam Peel (YP), Cassava Peel (CP), Cocoyam Peel (CoP) and Plantain Peel (PP) are } \\
\text { common food wastes of the Niger Delta region. Anaerobic Digestion (AD) of these } \\
\text { wastes with Water Hyacinth }(\mathrm{WH}) \text { presents a viable way of both providing renewable } \\
\text { energy and cleaning up the environment. Anaerobic digestion tests were carried out on } \\
\text { the food wastes and WH to determine their biogas potentials. The experiments were } \\
\text { carried out under mesophilic conditions at }(37 \pm 10 \mathrm{C}) \text { over a period of } 20 \text { days and the } \\
\text { tests were replicated to give an indication of repeatability. The results showed that } \\
\text { YP+WH, CP+WH, CoP+WH and PP+WH had specific biogas yields of } 0.42,0.29,0.39 \text {, } \\
\text { and } 0.38 \mathrm{~m} 3 / \mathrm{kg} \text { Volatile Solid }(\mathrm{VS}) \text { respectively. The yields represented } 76 \%, 48 \%, \\
70 \% \text { and } 69 \% \text { of their respective theoretical values. Co-digesting the food wastes with } \\
\mathrm{WH} \text { in the VS ratio of } 2: 1 \text { reduced the biogas yields of } \mathrm{YP}, \mathrm{CP}, \mathrm{CoP} \text { and PP by } 16 \% \text {, } \\
22 \%, 7 \% \text { and } 7 \% \text { respectively. The drop in gas production was due to indigestible } \\
\text { complex molecules in the WH co-substrate. The results indicate that common food } \\
\text { wastes in the Niger Delta can be used as feedstock for AD, but co-digesting with WH } \\
\text { reduces the biogas yield. }\end{array}$ \\
\hline
\end{tabular}




\section{Biogas Production Potential of Co-digested Food Waste and Water Hyacinth common to the Niger Delta}

Longjan, Gurumwal George* Dehouche, Zahir

College of Engineering, Design and Physical Sciences, Brunel University London, Uxbridge, UB8 $3 P H, U K$

Tel: +447552141851

Email: gurumwal.longjan.1@my.brunel.ac.uk

\section{Acknowledgement}

I would like to appreciate Community by Design for providing access to their Anaerobic Digester, and specifically Rokiah Yaman for providing technical expertise and a constant source of inoculum for the bio-methane tests. 


\title{
Biogas Production Potential of Co-digested Food Waste and Water Hyacinth common to the Niger Delta
}

\begin{abstract}
Yam Peel (YP), Cassava Peel (CP), Cocoyam Peel (CoP) and Plantain Peel (PP) are common food wastes of the Niger Delta region. Anaerobic Digestion (AD) of these wastes with Water Hyacinth $(\mathrm{WH})$ presents a viable way of both providing renewable energy and cleaning up the environment. Anaerobic digestion tests were carried out on the food wastes and WH to determine their biogas potentials. The experiments were carried out under mesophilic conditions at $\left(37 \pm 1^{\circ} \mathrm{C}\right)$ over a period of 20 days and the tests were replicated to give an indication of repeatability. The results showed that $\mathrm{YP}+\mathrm{WH}, \mathrm{CP}+\mathrm{WH}, \mathrm{CoP}+\mathrm{WH}$ and $\mathrm{PP}+\mathrm{WH}$ had specific biogas yields of $0.42,0.29,0.39$, and $0.38 \mathrm{~m}^{3} / \mathrm{kg}$ Volatile Solid (VS) respectively. The yields represented $76 \%, 48 \%, 70 \%$ and $69 \%$ of their respective theoretical values. Co-digesting the food wastes with WH in the VS ratio of 2:1 reduced the biogas yields of $\mathrm{YP}, \mathrm{CP}, \mathrm{CoP}$ and $\mathrm{PP}$ by $16 \%, 22 \%, 7 \%$ and $7 \%$ respectively. The drop in gas production was due to indigestible complex molecules in the WH co-substrate. The results indicate that common food wastes in the Niger Delta can be used as feedstock for $\mathrm{AD}$, but co-digesting with $\mathrm{WH}$ reduces the biogas yield.
\end{abstract}

Keywords: anaerobic digestion, biogas, food waste, Niger Delta, Water Hyacinth.

Word Count: 6,112 


\section{Introduction}

Nigeria is one of the largest producers of crude oil. Despite the abundant oil reserve, the country's energy sector struggles to meet energy demands. $52 \%$ of the population have no access to electricity while $75 \%$ of the population utilise traditional biomass like firewood for cooking [1]. The use of such traditional fuels is the major factor leading to an increase in desertification and change in the country's vegetation [2]. Harnessing renewable energy in Nigeria would help in addressing the energy shortfall. The clean energy would also mitigate environmental degradation from burning of traditional fuels.

A region that urgently requires the adoption of such renewable technologies is the Niger Delta region. The area is home to Nigeria's crude oil deposits and has suffered environmental degradation from resource extraction, oil spills and gas flaring. In addition to pollution from the oil and gas sector, the Niger Delta, which is located on a delta has suffered from the infestation of the aquatic weed water hyacinth. Its presence has led to negative effects on the socio-economic activities of the region. Another adverse effect of the watery terrain of the region is the difficulty it causes in extending the national power grid to the remote Niger Delta communities. The consequence is a lack of adequate power in the region that further promotes the use of firewood, enhancing deforestation. The absence of electricity also forces local households to utilise fuel based electric generators that further pollute the atmosphere with noxious greenhouse gases. Another notable source of pollution in the region is communal waste. This comes from the indiscriminate disposal of domestic and household wastes. The lack of sufficient policies on waste management has led to unsanctioned disposal methods including dumping of waste into the local water bodies and open air burning of household waste. 
These energy utilising and environmental degrading activities in the Niger Delta have the potential to deprive future generations of energy sources and healthy living conditions. Studies have shown that improved energy improves security, health and education and reduces poverty. There is a positive link between rural electrification, rural development, poverty alleviation and reduced environmental degradation [3].

Considering the energy and environmental challenges of the Niger Delta, a suitable clean energy technology for the region is anaerobic digestion (AD). The process involves the degradation of organic materials by microorganisms in oxygen-free environments for the production of biogas. The process consists of four main stages namely: hydrolysis, acidogenesis, acetogenesis and methanogenesis. In each of these stages, the original organic material is converted into intermediaries like organic acids and hydrogen, which eventually produce the biofuel methane. Biofuels produced from the anaerobic digestion of organic wastes addresses some of the environmental degradation issues of the Niger Delta. The potential feedstock for the digestion process would consists of both the organic fraction of communal wastes and the abundant problematic water hyacinth. Utilising water hyacinth as a feedstock would aid in mitigating its proliferation in the region. Furthermore the soil, water and atmosphere will benefit from the reduction in burying, dumping and burning of waste respectively. For regions that have poor energy infrastructure, biogas from $\mathrm{AD}$ can reduce the dependence on fossil fuels and help mitigate deforestation while improving the livelihood of rural populations [4]. Biogas from waste has been shown to reduce poverty and improve on the economic development in developing countries [5].

There has been extensive research in the biogas potentials of feedstocks that are common to the developed countries, such as energy crops, industrial waste and sewage sludge. In contrast there has been limited research on the biogas potentials of exotic 
food wastes common to rural Nigerian communities. This may be a result of laboratories in developing countries having almost no access to advanced gas measuring equipment, which limits research aimed at improving local biogas production [6].

Furthermore the FAOSTAT [7] database indicates that Nigeria is the world's largest producer of Yam (Dioscorea rotundata Poir.), Cassava (Manihot esculenta Crantz), Cocoyam (Colocasia esculenta (L.) Schott) at 40,500,000, 53,000,000 and $3,500,000$ tonnes respectively. This is in addition to producing some of the highest volumes of Plantain (Musa paradisiaca L.) at 2,780,000 tonnes. These four foods are the most commonly consumed in the Niger Delta based on consumption patterns [8], household expenditures [9] and farming practices [10]. These foods will undoubtedly produce high amounts of food waste, including Yam Peel (YP), Cassava Peel (CP), Cocoyam Peel (CoP) and Plantain Peel (PP) that can be used as feedstock for the anaerobic digestion process. Each of these potential feedstock will need to be characterised to determine their suitability as $\mathrm{AD}$ feedstock [11]. Additionally the distribution of protein, fats and carbohydrates in feedstock is important for assessing its fitness for the AD process [12]. Furthermore feedstock composition can be used to determine the retention time of a digester based on the various digestibility rates of different nutrients. Simple sugars, volatile fatty acids and alcohols are digested in hours, proteins and lipids in days while cellulose takes weeks to anaerobically degrade [13]. If data on the feedstock is available, it can be used for an initial evaluation of the suitability of the feedstock for digestion. This creates a need for the characterisation of Niger Delta food wastes and water hyacinth for the benefit of researchers, policy advisers and potential AD investors.

The current literature on the co-digestion of water hyacinth focuses on its synergistic effects on animal manure. There is limited data on the effects of co-digesting 
the plant with food waste. This study will evaluate the biogas potentials of common food wastes in the Niger Delta. The focus will be on their characterisation and biogas potential from co-digestion with water hyacinth. The research approach is experimental and uses conventional research methods in a new area of investigation.

\section{Materials and methods}

\subsection{Sample Collection}

Yam, Cassava, Cocoyam and Plantain were selected as the sources of food waste based on consumption patterns in the Niger Delta. They were sourced from the region and transported to Brunel University in preparation for the experiments. The wastes from the yam, cassava and cocoyam were obtained by using a kitchen knife to cut off thin slices of their outer coats. The plantains waste is obtained by using a kitchen knife to make a $5 \mathrm{~mm}$ insertion into the top of the plantain and making a cut to the bottom. The outer coat is then cleanly pulled off by hand. Their respective food wastes are Yam Peel (YP), Cassava Peel (CP), Cocoyam Peel (CoP) and Plantain Peel (PP). Sourcing the water hyacinth from the Niger Delta was not possible due to EU and UK regulations concerning water hyacinth, hence the fresh water hyacinth was obtained from Anglo Aquatic Plant Enfield, an agricultural nursery that specialises in aquatic plants.

The peels and $\mathrm{WH}$ were decontaminated by rinsing with deionized water to remove dust, coarse particles and other extraneous contaminants that could adversely affect the test results. Sub-samples of the substrates were then sent to NRM Laboratories Bracknell, where their nutrient characteristics were determined using standard analytical tests for total and volatile solids, ash, crude protein, fibre and oils. The results are presented in Table 1. 


\subsection{Waste Content and Specific Waste Index}

The waste content of each food sample was determined by extracting and weighing the inedible part of the food and determining its proportion in the weight of the whole food. The weight of the foods and wastes were measured using an Adam Equipment PGL 2002 Analytical Balance. The tests were performed in triplicates to improve precision. The organic waste content was determined as the proportion of the food waste that is organic in nature. The results were used to calculate the Specific Waste Index of the various foods which is the ratio of the weight of their individual wastes to that of their respective consumable parts [14]. The equation is shown in (1).

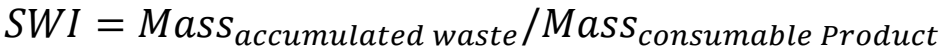

\subsection{Substrate preparation}

The sample peels were cut into $2 \mathrm{~cm}$ pieces and then heat dried in a Thermo Scientific box furnace at $80^{\circ} \mathrm{C}$ for 24 hours in order to stabilize the tissue and stop enzymatic reactions. The procedure was based on Campbell and Plank [15] who observed that plant samples dried below $80^{\circ} \mathrm{C}$ might not lose all moisture and above that temperature may lead to thermal decomposition and reduce the dry weight of the sample. After drying, the various peels were individually ground in a Waring WSG30 high-speed mill into fine powder and sieved through a mesh of $0.5 \mathrm{~mm}$. The milling process also homogenised the samples.

\section{$2.4 \quad$ Inoculum}

The inoculum/active biomass was obtained from the $2 \mathrm{~m}^{3}$ Anaerobic Digestion plant at Camley Street Natural Park, London. The digester has been running for two years and is fed catering food wastes consisting of fruit and vegetable peels, eggshells, coffee 
grounds, chips and bacon from local canteens.

\subsection{Inoculum Preparation}

The inoculum was sieved through a $0.5 \mathrm{~mm}$ mesh in order to remove coarse particulates and thus increase the Volatile Solid (VS) to Total Solid (TS) ratio. The inoculum had a TS content of $5 \%$ and a VS content of $3 \%$, indicating a VS/TS of $62 \%$. These values met up to the VDI 4630 [22] requirement of the inoculum having at least 50\% VS/TS.

$0.5 \mathrm{~kg}$ of the inoculum was measured into each of nine 0.51 bioreactor vessels, sealed and then sparged with nitrogen to create an anaerobic environment. The vessels were then placed in a water bath set to $\left(37 \pm 1^{\circ} \mathrm{C}\right)$. The setup was allowed to run for seven days in order to degas the microbes, thus reducing the biogas contribution of the inoculum by means of a "hunger phase". The process also allowed the microbes to adapt to the new environmental conditions.

\subsection{Anaerobic Digestion Batch Tests}

The anaerobic digestion tests were performed in line with the guidelines set by VDI 4630 [22] for standardized fermentation test. Nine bioreactor vessels in a heating bath were used to perform the AD tests in duplicates. The vessels were distributed between various batches of the tests to provide randomisation. Prior to testing, the vessels were washed and disinfected with isopropanol to eliminate any microbial activity that might contaminate the process.

In each test batch, there were four pairs of vessels which each received $8.4\left(10^{-3}\right.$ $\mathrm{kg}$ ) VS of substrate. In the case of anaerobic co-digestion, a C/N (Carbon to Nitrogen ratio) of 20-30 was not used for the feedstock due to the recalcitrant nature of the water hyacinth co-substrate. A high amount of the Carbon in the plant is locked in lignocellulosic molecules, which are unavailable to the AD microbes. Hence any 
digestion projection using such Carbon content will not provide a realistic outcome. For this study, the $8.4\left(10^{-3} \mathrm{~kg}\right)$ VS allocation for feedstock was divided in the ratio $2: 1$ between the food waste and water hyacinth. The pre-treated inoculum was measured into $0.5 \mathrm{~kg}$ batches and then added to each of the eight vessels containing waste samples, while the ninth vessel consisted of only $0.5 \mathrm{~kg}$ of inoculum and served as the blank test that provided the gas contribution of the inoculum. All vessels were thoroughly mixed to maximise contact between the substrates and the microbes.

The vessels were then sealed and sparged with Nitrogen to create an anaerobic environment. The nine reactors were then placed in a shaking water bath at the mesophilic temperature of $\left(37 \pm 1{ }^{\circ} \mathrm{C}\right)$ and shaking rate of 100 strokes per minute for agitation.

An inline biogas analyser was connected to the reactor vessels and used to determine the percentage of methane, propane and carbon dioxide in the biogas every 15 minutes during the BMP test period. Biogas production was measured by gas collection in inverted graduated $500 \mathrm{ml}$ cylinders, while readings were taken twice daily for the first 3-5 days when there was rapid gas production. Subsequently the readings were taken daily to make the course of gas formation recognisable. Cumulative flow graphs were drawn from the recorded data to determine the gas production curves. The retention time was 20 days for each batch. That time was sufficient for the daily gas production rate to drop to less than $1 \%$ of the cumulative gas produced up to that moment, which is in line with VDI 4630 guidelines. The Specific Biogas Yield (SBY) of the food wastes were determined by deducting the biogas contribution of the inoculum from the cumulative biogas production of the food wastes. 


\section{Results and Discussion}

\subsection{Food Waste Content}

The Specific Waste Index (SWI) of the four food samples ranged from $0.3-0.5$ with an average value of 0.4 . The results indicated that plantain had the highest SWI of 0.5 while cassava had the lowest value at 0.3 . The average waste content of the four food items is $26 \%$ while their average organic waste content is $6 \%$. Plantain had the highest waste content of $34 \%$ of which just $14 \%$ of that amount was organic in nature. Yam had the second highest waste content of $25 \%$ of which $34 \%$ was organic in nature. The lowest amount of waste was from cassava at $20 \%$.

The statistical analysis of the waste contents was performed using the nonparametric Kruskal-Wallis test. The results indicated that there was a significant difference $(p<0.05)$ between the amounts of waste produced from the four foods. The non-parametric post-hoc Dunn's test was used to identify which samples were significantly different from each other. The results identified only cassava and plantain as having a significant difference between their waste contents.

Yam and cassava have high variations in waste content due to the differences in the sizes of their individual tubers and the variation in the amount of edible components that are cut off with the peels. Plantains have the least variations in waste content as a result of the similar sizes of plantains. Additionally the peels of plantains are easily removed without any of the edible parts of the plantain. The SWI values for the three ground tubers of yam, cassava and cocoyam are close to the values for another ground crop, potato at $0.3-0.5$, obtained by Russ and Meyer-Pittroff [14]. The results show that foods can have high waste contents but the wastes will consist of low organic proportions. 
Foods with high SWI are ideal as sources of potential feedstock that will be considered in the anaerobic digestion chain. If SWI is the only factor, plantain is the ideal feedstock. However, when considering the organic content of the food waste, yam becomes the ideal choice. The implication is that both factors of total waste and organic waste content have to be considered when selecting an appropriate food for its waste as AD feedstock.

\subsection{Food Waste and Water Hyacinth Characterization}

Results from the characterisation of the food waste revealed that the Total Solid content varied widely between samples. The values ranged from $7.2 \%$ for water hyacinth to $36.6 \%$ for yam peels with an average value of $22.6 \%$. Results of the VS/TS analysis showed that plantain peels and water hyacinth had the lowest values at $88.3 \%$ while cassava peels had the highest value at $95.6 \%$. Crude protein values ranged from $7.4 \%$ $\mathrm{VS}^{-1}$ for plantain peels to $20 \% \mathrm{VS}^{-1}$ for water hyacinth while crude fibre content ranged from $7.0 \% \mathrm{VS}^{-1}$ for yam peels to $20 \% \mathrm{VS}^{-1}$ for water hyacinth. The oil contents of the samples were all below $5.1 \% \mathrm{VS}^{-1}$ with the exception of cassava peels, which had a relatively high value of $24.6 \% \mathrm{VS}^{-1}$ due to the wax used in its preservation process [18]. The Nitrogen Free Extracts (NFE) made up the highest nutrient proportion of the volatile solids in all the samples. The value was as high as $82.2 \% \mathrm{VS}^{-1}$ for yam peels to $55.0 \% \mathrm{VS}^{-1}$ for water hyacinth. Water hyacinth had the highest ash contents at $16.7 \%$ due to its roots having a high affinity for accumulation of metals [19].

The TS of the samples were within the range of energy crops of $15-40 \%$ as reported by Al Seadi et al. [13]. Low TS feedstock increase digester volume with low nutrient content while those with high TS require additional water when digested [12]. The VS/TS results of YP, CP and CoP were above the range of VS/TS for energy crops 
and plant wastes of $70-90 \%$ as reported by Al Seadi et al. [13] and Neureiter [16]. Feedstocks with VS/TS below $60 \%$ are not suitable for the AD process [12].

Excessive amounts of any of the nutrients can have detrimental effects on the AD process. High amounts of protein can lead to high ammonia concentrations while high fibre content can cause foaming and lignin incrustation in digesters. High oil content can lead to longer retention times and accumulation of fatty acids.

\subsection{Theoretical Bio-methane Potential}

The results of the theoretical Bio-Methane Potential analysis showed a narrow range of $549.2-619.0 \mathrm{~m}^{3} / \mathrm{g}$ VS for biogas yields. The methane content varied between $52.0-$ $57.4 \%$. The biogas potentials are within the range of biogas yields of corn, barley, crude glycerine and wheat grains as reported in NNFCC [20]. CP had the highest biogas and methane potential at $619.0 \mathrm{~m}^{3} / \mathrm{g} \mathrm{VS}$ and $57.4 \%$ respectively. While the lowest biogas and methane potentials were from YP at $549.2 \mathrm{~m}^{3} / \mathrm{g}$ VS and $52 \%$ respectively.

When considering the biogas potentials of the Fresh Weight (FW) of the samples, there was a high variation in potential yield, ranging from $33.3-188.4 \mathrm{~m}^{3} / \mathrm{t}$ FW with an average potential of $119.0 \mathrm{~m}^{3} / \mathrm{t} \mathrm{FW}$. YP had the highest potential at 188.4 $\mathrm{m}^{3} / \mathrm{t} \mathrm{FW}$ followed by CP at $173.3 \mathrm{~m}^{3} / \mathrm{t} \mathrm{FW}$. Next was CoP at $123.6 \mathrm{~m}^{3} /$ tonne and lastly PP with the least potential at $76.4 \mathrm{~m}^{3} /$ tonne.

The theoretical biogas yields on a VS basis present the biogas potential of the feedstock in respect of the organic dry matter content of the sample. The yield on a fresh weight basis presents the theoretical results of yield from the wet weight of the sample. CP had the highest biogas potential per mass of VS and the highest methane content. When considering the wet weight, it has the second highest yield. Its high moisture content of $70.7 \%$ would cause a low nutrient concentration in a digester leading to lower energy output. YP had the highest fresh weight biogas potential while 
PP had the least potential at $76.4 \mathrm{~m}^{3} /$ tonne. There was a direct correlation between moisture content and low wet weight biogas yields. The higher the moisture content, the lower the wet weight biogas yields.

The range of results for biogas yields on a VS basis corresponds to a wide variety of feedstock found in literature. Feedstock with similar yields include vegetable waste, potato waste, food waste, fruit waste, slaughterhouse waste and household waste as reported by Deublein and Steinhauser [21]. This signifies that the theoretical biogas potentials of Niger Delta food wastes are within the range of values from conventional AD substrates. This suggests their suitability as candidates for AD feedstock. Their actual biogas yields will be lower than their theoretical values due to the presence of non-degradable material. Additionally microbes consume 3-10\% of the substrates for their growth [22].

Comparing the study's wet weight biogas potentials with results reported in Korres et al. [23], the theoretical yield of $\mathrm{WH}$ at $33.3 \mathrm{~m}^{3} /$ tonne was higher than the reported $14.7 \mathrm{~m}^{3} /$ tonne. Yam and cassava peel yields were within the range of values of crops such as barley, rye, sugar beet and rice straw, which ranged from 156.6 - 266.6 $\mathrm{m}^{3} /$ tonne.

The Spearman's Rank Order Correlation was used to test if there was a correlation between the various characteristics of the food wastes and their biogas yields. The results showed a perfect correlation between the FW biogas yields and the TS and VS content. There was also a strong relationship between the yields and the VS/TS ranking. This implies that the TS or VS content of various feedstocks in a group can be used to determine which feedstock will produce more or less biogas than other members of the group. For the biogas yield on VS basis, there was a moderate relationship with the TS and VS content. Methane content had a strong correlation with 
moisture and oil content of the feedstock. The relationship is not perfect, so should be used cautiously when estimating which feedstocks have higher methane contents.

\subsection{Biogas Production of Co-digested Food Waste}

\subsubsection{Biogas Yields of Co-Digested Substrates}

The results from the BMP tests showed that $\mathrm{YP}+\mathrm{WH}$ had the highest biogas yield at $419 \mathrm{ml} / \mathrm{g}$ VS. Next were CoP+WH and PP+WH at $387.53 \mathrm{ml} / \mathrm{g}$ VS and $382.46 \mathrm{ml} / \mathrm{g} \mathrm{VS}$ respectively. $\mathrm{CP}+\mathrm{WH}$ had the lowest yield at $285.21 \mathrm{ml} / \mathrm{g}$ VS. The low yield of the $\mathrm{CP}+\mathrm{WH}$ was expected because studies had shown that the cyanide content of the cassava peels was detrimental to the AD microbes especially the methanogens [24-26].

The results of the daily gas production showed that biogas production peaked within the first three days for all the samples. The peak gas productions for the YP+WH and $\mathrm{PP}+\mathrm{WH}$ were on the second day, while for the $\mathrm{CoP}+\mathrm{WH}$ and $\mathrm{CP}+\mathrm{WH}$ it was on the third day. This implied a rapid consumption of the readily available nutrients by the microorganisms and subsequent rapid conversion of the intermediate products to final products. By the fourth day, gas production was in the retardation phase. The gas production curves are shown in Figure 1.

Most of the biogas yields were obtained within the first six days, with $\mathrm{YP}+\mathrm{WH}$, $\mathrm{CP}+\mathrm{WH}, \mathrm{CoP}+\mathrm{WH}$ and $\mathrm{PP}+\mathrm{WH}$ producing $80 \%, 70 \%, 75 \%$ and $71 \%$ of their total production by the sixth day.

The Biodegradability (BD) of the substrates, which is the percentage of the theoretical to the measured biogas yields [27], were determined. The theoretical yields were calculated using the Baserga model, which uses the nutrient composition of each substrate to calculate their theoretical biogas potential. The model assumes that all nutrients are converted to biogas. $\mathrm{YP}+\mathrm{WH}$ had the highest biodegradability at $76.1 \%$. 
Next were $\mathrm{CoP}+\mathrm{WH}$ and $\mathrm{PP}+\mathrm{WH}$ with values of $70.2 \%$ and $68.5 \%$ respectively. Least biodegradable was $\mathrm{CP}+\mathrm{WH}$, which had a low value of $47.9 \%$.

The variation between theoretical and actual values is occasioned by the presence of complex nutrients in plant-based feedstock, inhibitory factors and the consumption of nutrients by microbes for their growth. Drosg et al. [11] stated that plant based feedstock attained $50-70 \%$ of their theoretical values when anaerobically digested. The results show that $\mathrm{YP}+\mathrm{WH}, \mathrm{PP}+\mathrm{WH}$ and $\mathrm{CoP}+\mathrm{WH}$ were either within or surpassed the range while the biodegradability of $\mathrm{CP}+\mathrm{WH}$ was below the lower limit.

Despite $\mathrm{CP}+\mathrm{WH}$ having the highest theoretical value of biogas production, the actual digestion produced a very low amount of biogas. This is caused by the cyanide content of the cassava peels, which adversely affects the AD microbes [25-26]. A method was developed by Cuzin and Labat [24] to reduce the cyanide levels during the AD of cassava peels, to a non-inhibitory concentration. The method utilised cyanide detoxification enzymes in a plug flow digester to reduce the cyanide concentration. Cumbana et al. [28] used a "Wetting Method" to also reduce the cyanide content of the plant. The process involved mixing the cassava with water and spreading it out to dry in a thin layer. Bradbury and Denton [29] modified an earlier wetting method and lowered the time taken to reduce the cyanide content to two hours, reducing the original method by three fold. This was accomplished by drying the mixture in the sun rather than the shade. Such methods could improve the gas production from the anaerobic digestion and co-digestion of cassava peels.

The difference between the measured biogas and the theoretical yield may be reduced by chemical pre-treatment of the substrates. This would break down the lignin and other complex molecules into shorter chains that can be readily consumed by the microbes. Studies by Patil et al. [30], Cheng et al. [17], Gao et al. [31] and Cheng et al. 
[32] showed that using chemicals to pre-treat water hyacinth reduced lignin and broke down crystalline cellulose. In each of the studies, biogas production increased after pretreatment. In order to reduce the difference between measured and theoretical values of the samples, chemical pre-treatment and reduction of inhibiting substances from the feedstock need to be implemented.

The $\mathrm{pH}$ values of the BMP tests over the 20-day period varied between 7 and 8 . In all tests the $\mathrm{pH}$ values fell within the first two days, indicating the presence of organic acids. After the second day, there was a steady increase in $\mathrm{pH}$ values, and from the eighth day, the values remained steady. The final $\mathrm{pH}$ values for the samples were between 7.75 and 7.93 , indicating that there was no accumulation of excess organic acids. This implied that the substrate to inoculum ratio of 1:2 VS was sufficient enough to prevent any acid build up.

\subsubsection{Kinetics}

The cumulative biogas production curves were fitted to the Modified Gompertz Model shown in (2) using non-linear regression:

$M=P \times \exp \left\{-\exp \left[\frac{R_{m} \times e}{P}(\lambda-t)+1\right]\right\}$

Where $M$ is the Cumulative Biogas Production ( $\mathrm{ml} / \mathrm{g} \mathrm{VS}$ ), $\lambda$ is the Lag Phase (days), $t$ is the Digestion Period (days), $R_{m}$ is the Maximum Biogas Production Rate $(\mathrm{ml} / \mathrm{g}$ VS/day), $P$ is the Biogas Production Potential (ml/g VS) and $e$ is 2.718282.

The model gives the cumulative biogas production from batch digesters. The results are presented in Tables $2 \mathrm{a}$ and $2 \mathrm{~b}$. In all results, the measured biogas was more than the simulated values. The respective simulated biogas values of $\mathrm{YP}+\mathrm{WH}, \mathrm{CP}+\mathrm{WH}$, $\mathrm{CoP}+\mathrm{WH}$ and $\mathrm{PP}+\mathrm{WH}$ were $94.5 \%, 94.5 \% 95.9 \%, 95.5 \%$ of their measured values. 
The model curves had a very close fit to the gas production curves indicating the measured biogas yields are in agreement with the simulated values. This is confirmed by the high values of $\mathrm{R}^{2}$ ranging from 0.9289 for $\mathrm{YP}+\mathrm{WH}$ to 0.9586 for $\mathrm{PP}+\mathrm{WH}$. The conclusion is that these results can be used to validate the Modified Gompertz Model.

The lag phase, which is the minimum time required for the microorganisms to adapt to the environment and commence gas production was less than five hours in all tests. This is because the inoculum had been acclimatised to the bioreactor environment for a week prior to the BMP test. The process degassed the microbes and created a hunger phase. This led to an early consumption of the readily available components of the introduced substrate. The microbial activity led to instant gas productions thereby reducing the lag phase.

The T80 or Technical Digestion Time is the time needed to produce $80 \%$ of the total gas production [33]. For the various substrates, $\mathrm{YP}+\mathrm{WH}$ had the shortest T80 period of 6 days. This indicates a rapid consumption and conversion of available nutrients. The longest T80 was for the $\mathrm{CP}+\mathrm{WH}$ at 8.4 days. This could have resulted from the toxic effect of cyanide on the microbes, leading to a reduction in the microbial population. This would cause the remaining microbes to take longer periods to consume the available nutrients. The $\mathrm{T} 80$ values for the $\mathrm{CoP}+\mathrm{WH}$ and $\mathrm{PP}+\mathrm{WH}$ were 6.8 days and 7.4 days respectively. The T80 period can be used as a benchmark for the retention period or Hydraulic Retention Time of an AD process.

\subsubsection{Biogas composition}

The methane and carbon dioxide content were automatically analysed by an inline NonDispersive Infra Red (NDIR) biogas sensor. The sampling period was every 15 minutes. The average daily results are presented in Figure 2. For all the samples, the initial biogas production consisted mainly of carbon dioxide with a lower amount of methane. 
The switch from a higher carbon dioxide content to a higher methane content occurred on the second day for $\mathrm{CoP}+\mathrm{WH}$ and $\mathrm{PP}+\mathrm{WH}$ and on the third day for both $\mathrm{YP}+\mathrm{WH}$ and $\mathrm{CP}+\mathrm{WH}$. The highest average daily methane concentrations for $\mathrm{YP}+\mathrm{WH}, \mathrm{CP}+\mathrm{WH}$, $\mathrm{CoP}+\mathrm{WH}$ and $\mathrm{PP}+\mathrm{WH}$ were $37.2,23.5,37.8$ and $39.7 \%$ respectively. The $\mathrm{CoP}+\mathrm{WH}$ was the first to attain its maximum methane concentration by the third day, while the remaining three samples each attained their maximum values on the fourth day. As explained previously, the very low methane content in the $\mathrm{CP}+\mathrm{WH}$ is a result of the cyanide content which is toxic to microbes especially the methanogens [24-26]. The variation in the biogas composition support the understanding that methane and carbon dioxide content of biogas varies widely between the beginning, middle and end of a BMP batch test. The implication is that a single gas analysis test is not sufficient to determine the methane content of the biogas yield of a feedstock. There needs to be multiple sample points in order to determine the true methane potential of a substrate. The average methane content of the whole duration of the experiment would give a false methane content result because it would include the very low residual methane content at the end of the test. It is more practical to determine the average value for specific time frames. From the biogas yield results, the T80 period corresponds to the peak biogas yields.

Consequently the average methane content was calculated for the T80 period, the remaining retention time (t-T80 days) and the whole duration of the test (t days). The results show that the average methane content during the T80 period is far higher than the other two periods measured. For all the samples, the average methane content for the T80 period was approximately three times the average content for the rest of the retention period (t-T80) and approximately twice the average content for the whole digestion period $(\mathrm{t})$. This leads to a conclusion that it is necessary to take multiple gas 
samples for the biogas analysis during the AD process. It is also necessary to focus on the samples taken during the T80 period, since that could also serve as the retention time in a full scale digester.

\subsubsection{Statistical analysis}

The biogas yield results were evaluated using the Kruskal-Wallis test. The results indicated that there was no significant difference $(\mathrm{p}>0.05)$ between the groups. They were analysed using the SPSS IBM software package.

\subsection{Biogas Potential of Mono-Digested Food Waste}

\subsubsection{Biogas Yields of Mono-Digested Substrates}

YP produced the highest Specific Biogas Yield of $551 \mathrm{ml} / \mathrm{g}$ VS. Next were CoP and PP at $414 \mathrm{ml} / \mathrm{g}$ VS and $412 \mathrm{ml} / \mathrm{g}$ VS respectively. The least yield was from CP at $367 \mathrm{ml} / \mathrm{g}$ VS. As explained in section 3.4, the low biogas yield for the CP was likely a result of the toxic effect of cyanide on microbes, leading to AD inhibition. From the results, the mono-digested substrates are ranked in the same order of highest to lowest biogas yields as their co-digested counterparts in terms of biogas production. The biogas yields had standard deviations of less than $3 \%$ indicating values are very close to the mean.

The biodegradability analysis showed that YP had the highest biodegradability at $100.3 \%$. Next were CoP and PP at $75.1 \%$ and $73.4 \%$ respectively. The lowest was CP at $59.3 \%$. The high biodegradability of YP suggests that there was some synergetic activity in the digester that helped to improve the biogas yield beyond its theoretical values. The high biodegradability is supported by the YP having very high amounts of NFEs at $82.2 \%$ which are soluble carbohydrates easily consumed by microbes. The low biodegradability of $\mathrm{CP}$ results from the presence of cyanide, which adversely affects 
AD microbes. The toxins most likely led to an inefficient consumption of the available nutrients due to incapacitated microbes. This would explain the large variation between the measured and theoretical values, since the theoretical values are based on complete nutrient conversion. The biogas productions of the mono-digested food waste were closer to their theoretical values than the co-digested samples.

The gas production curves are shown in Figure 3. The daily and cumulative biogas production curves showed little variations between the replicates. Gas production for the YP, CP and PP peaked on the second day while for CoP it was on the fourth day.

Similar to the gas production profile of the co-digested substrates, by a quarter of the retention time, most of the gas had been produced by the samples. The percentage of biogas produced by the sixth day for $\mathrm{YP}, \mathrm{CP}, \mathrm{CoP}$ and $\mathrm{PP}$ were $83 \%, 79 \%, 75 \%$ and $71 \%$ respectively. It was an improvement for the $\mathrm{CP}$, whose co-digested counterpart produced $70 \%$ of the total biogas by the same period. The YP also improved from the $80 \%$ of its co-digested counterpart. For the CoP and PP the values were unchanged. The final $\mathrm{pH}$ values for the samples were between 7.09 to 7.96 , with $\mathrm{CP}$ having the lowest final $\mathrm{pH}$ value.

\subsubsection{Effect of water hyacinth on co-digestion}

The Specific Biogas Yields of the food wastes were compared to the yields of their codigested counterparts. For yam, cassava, cocoyam and plantain peels, co-digesting them with water hyacinth in the ratio $2: 1 \mathrm{VS}$, reduced their biogas yields by $16.2,22.3,6.5$ and $7.2 \%$ respectively. The yam and cassava peels had a higher loss in biogas production compared to the cocoyam and plantain peels.

Water hyacinth has recalcitrant nutrients consisting of lignin, cellulose and hemicellulose which AD microbes have difficulty digesting, leading to its low gas yield. Despite this disadvantage, chemical pre-treatment of water hyacinth would break up the 
complex molecules freeing up nutrients for the microbes, leading to an increase in biogas production [17, 30-32]. Ganesh et al. [34] extracted VFAs from water hyacinth using diluted cow dung. The process eliminated the indigestible fibres. Freeing up the nutrients has the possibility of increasing the biogas yields from co-digesting food waste with water hyacinth. Gunnarsson and Peterson [35] suggested longer retention times rather than expensive pre-treatment methods. In the case of water hyacinth, it is doubtful if longer retention times would free up the complex nutrients due to the complexity of its fibres.

\subsubsection{Model Kinetics}

The lag phase ranged from 0 to 14.6 hours in all tests. As explained in section 3.4 , the inoculum had already been preconditioned and starved of nutrients. This led to an immediate consumption of added substrates leading to early biogas production. The shortest T80 was by YP at 5.3 days. CP and PP were next at 6.3 and 6.8 days. The longest period was for PP at 7.4 days. The T80 period for YP and CP increased by 14 and $34 \%$, when co-digested with water hyacinth. This indicates that water hyacinth has an antagonistic effect on YP and CP that led to an increase in their retention period. The T80 results were the same for both the mono and co-digestion of CoP and PP. Since the T80 can be used as a reference for the retention time of digesters, mono digested yam and cassava peels would spend less time being digested in an anaerobic digester than when co-digested with water hyacinth. Similar to the co-digested results, the measured biogas was more than the predicted values. The respective simulated biogas values of YP, CP, CoP and PP were $94.4 \%, 92.9 \% 97.3 \%, 96.7 \%$ of their measured values.

There was a good fit of the model and gas production curves supported by $\mathrm{R}^{2}$ values of 0.9539 to 0.9749 . This confirms that the measured values are in agreement 
with the simulated values. The mono-digested results have a better fit than their codigested counterparts.

\subsubsection{Statistical analysis}

Kruskal-Wallis tests of the results showed that there was no significant difference between the groups $(\mathrm{p}>0.05)$.

\section{Conclusion}

The Niger Delta region consumes high quantities of yams, cassavas, plantains and tubers. These foods produce significant amounts of waste. This study confirms the suitability of utilizing these common food wastes as feedstock for the anaerobic digestion process. Additionally, water hyacinth may be used as a co-feedstock in the digestion process, which would help in reducing the infestation of the aquatic weed. A drawback to utilising the water hyacinth in the AD process is that it reduces the overall bioenergy yields of the feedstock by increasing the proportion of recalcitrant complex molecules, which are difficult to digest by the AD microbes. To mitigate the adverse effect of co-digesting with water hyacinth, the plant could be pre-treated to shorten its complex fibre chains, making them available for consumption by the microorganisms. Of all the samples tested, yam peel is shown to have the highest biogas potential. This food waste should be prioritised as biofuel raw material. In contrast, cassava peel has

the lowest bioenergy potential due to its cyanide content, which is toxic to AD microbes. Hence it should be the last option as a biofuel if there are other alternatives. Further research is required to determine the effect of detoxifying the cassava peel on the co-digestion process. The successful implementation of anaerobic digestion as a renewable energy technology will not only provide a clean source of energy for an energy deficit region, but it will also help in mitigating environmental degradation from 
household wastes and water hyacinth infestation.

\section{References:}

1. IEA. World Energy Outlook 2013. International Energy Agency: Tokyo, Japan (2013).

2. GOPA-International Energy Consultants. The Nigerian Energy Sector 2nd ed. (2015).

3. IEG. The Welfare Impact of Rural Electrification: A Reassessment of the Costs and Benefits. (2008).

4. Thien Thu CT, Cuong PH, Hang LT, et al. Manure management practices on biogas and non-biogas pig farms in developing countries - using livestock farms in Vietnam as an example. J.Clean.Prod. 27, 64-71 (2012).

5. Teune B. The biogas programme in Vietnam; amazing results in poverty reduction and economic development. Boiling Point(53), 11-13 (2007).

6. Pham CH, Triolo JM, Thu CTT, Pedersen L, Sommer SG. Validation and recommendation of methods to measure biogas production potential. Presented at: 15th Aaap Animal Science Congress, Thailand.

7. FAOSTAT. Production/Crops World 2013. 2015(November/20) (2015).

8. Ene-Obong HN, Sanusi RA, Udenta EA, et al. Data collection and assessment of commonly consumed foods and recipes in six geo-political zones in Nigeria: Important for the development of a National Food Composition Database and Dietary Assessment. Food Chem. 140(3), 539-546 (2013).

9. NBS (National Bureau of Statistics). Consumption Pattern in Nigeria 20092010. (2012b).

10. NDDC. Niger Delta Regional Development Master Plan. (2006).

11. Drosg B, Braun R, Bochmann G, Al Saedi T. 3 - Analysis and characterisation of biogas feedstocks. In: The Biogas Handbook. Wellinger A, Murphy J, Baxter D (Eds.), Woodhead Publishing, 52-84 (2013).

12. Steffen R, Szolar O, Braun R. Feedstocks for anaerobic digestion. Institute for Agrobiotechnology Tulln, University of Agricultural Sciences, Vienna (1998).

13. Al Seadi T, Rutz D, Prassl H, et al. Biogas Handbook.-University of Southern Denmark Esbjerg (2008). 
14. Russ W, Meyer-Pittroff R. Utilizing waste products from the food production and processing industries. Crit.Rev.Food Sci.Nutr. 44(1), 57-62 (2004).

15. Campbell C, Plank C. Preparation of plant tissue for laboratory analysis. In: Handbook of reference methods for plant analysis. Kalra Y (Ed.), CRC Press, Boca Raton, 37-41 (1997).

16. Neureiter M. Maize and maize silage for biomethane production. Bioenergy Production by Anaerobic Digestion: Using Agricultural Biomass and Organic Wastes, 74 (2013).

17. Cheng J, Xie B, Zhou J, Song W, Cen K. Cogeneration of H2 and CH4 from water hyacinth by two-step anaerobic fermentation. Int $\mathbf{J}$ Hydrogen Energy. 35(7), 3029-3035 (2010).

18. Onyenwoke, C. A., Simonyan, KJ. Cassava post-harvest processing and storage in Nigeria: A review. African Journal of Agricultural Research. 9(53), 38533863 (2014).

19. Weis JS, Weis P. Metal uptake, transport and release by wetland plants: implications for phytoremediation and restoration. Environ.Int. 30(5), 685-700 (2004).

20. NNFCC (National Non-Food Crops Centre). Feedstocks. 2016(June/2016) (2016).

21. Deublein D, Steinhauser A. Biogas from waste and renewable resources: an introduction. John Wiley \& Sons (2011).

22. VDI 4630. VDI 4630: Fermentation of organic materials- Characterisation of the substrate, sampling, collection of material data, fermentation tests. (2006).

23. Korres, Nicholas E.,, O'Kiely, Padraig,, Benzie, John A. H.,,West, Jon,. Bioenergy production by anaerobic digestion : using agricultural biomass and organic wastes. (2013).

24. Cuzin N, Labat M. Reduction of cyanide levels during anaerobic digestion of cassava. Int.J.Food Sci.Tech. 27(3), 329-336 (1992).

25. Cuzin N, Farinet JL, Segretain C, Labat M. Methanogenic fermentation of cassava peel using a pilot plug flow digester. Bioresour.Technol. 41(3), 259-264 (1992).

26. Ubalua A. Cassava wastes: treatment options and value addition alternatives. African Journal of Biotechnology. 6(18), 2065-2073 (2007). 
27. Triolo JM, Pedersen L, Qu H, Sommer SG. Biochemical methane potential and anaerobic biodegradability of non-herbaceous and herbaceous phytomass in biogas production. Bioresour.Technol. 125, 226-232 (2012).

28. Cumbana A, Mirione E, Cliff J, Bradbury JH. Reduction of cyanide content of cassava flour in Mozambique by the wetting method. Food Chem. 101(3), 894897 (2007).

29. Bradbury JH, Denton IC. Rapid wetting method to reduce cyanogen content of cassava flour. Food Chem. 121(2), 591-594 (2010).

30. Patil J, AntonyRaj A, Gavimath C. Study on effect of pre-treatment methods on biomethanation of water hyacinth. International Journal of Advanced Biotechnology and Research. 2(1), 143-147 (2011).

31. Gao J, Chen L, Yan Z, Wang L. Effect of ionic liquid pretreatment on the composition, structure and biogas production of water hyacinth (Eichhornia crassipes). Bioresour.Technol. 132, 361-364 (2013).

32. Cheng J, Xia A, Su H, Song W, Zhou J, Cen K. Promotion of H2 production by microwave-assisted treatment of water hyacinth with dilute $\mathrm{H} 2 \mathrm{SO} 4$ through combined dark fermentation and photofermentation. Energy Conversion and Management. 73, 329-334 (2013).

33. Palmowski L, Müller J. Influence of the size reduction of organic waste on their anaerobic digestion. Water Science and Technology. 41(3), 155-162 (2000).

34. Ganesh PS, Ramasamy EV, Gajalakshmi S, Abbasi SA. Extraction of volatile fatty acids (VFAs) from water hyacinth using inexpensive contraptions, and the use of the VFAs as feed supplement in conventional biogas digesters with concomitant final disposal of water hyacinth as vermicompost. Biochem.Eng.J. 27(1), 17-23 (2005).

35. Gunnarsson CC, Petersen CM. Water hyacinths as a resource in agriculture and energy production: A literature review. Waste Manage. 27(1), 117-129 (2007). 
Table 1. Characterisation of four Niger Delta food wastes and water hyacinth.

\begin{tabular}{|c|c|c|c|c|c|}
\hline Food Waste & Water Hyacinth & Yam Peels & Cassava Peels & $\begin{array}{l}\text { Cocoyam } \\
\text { Peels }\end{array}$ & Plantain Peels \\
\hline SWI & - & 0.34 & 0.25 & 0.32 & 0.52 \\
\hline Total Solids (\%) & 7.2 & 36.6 & 29.3 & 24.5 & 15.4 \\
\hline $\begin{array}{l}\text { Volatile Solids } \\
\text { (\% TS) }\end{array}$ & 83.3 & 93.7 & 95.6 & 91.4 & 88.3 \\
\hline $\begin{array}{l}\text { Crude Protein } \\
\text { (\% VS) }\end{array}$ & 20 & 9.6 & 8.6 & 10.7 & 7.4 \\
\hline $\begin{array}{l}\text { Oil-B } \\
\text { (\% VS) }\end{array}$ & 5 & 1.2 & 24.6 & 1.8 & 4.4 \\
\hline $\begin{array}{l}\text { Nitrogen Free Extract } \\
(\% \mathrm{VS})\end{array}$ & 55 & 82.2 & 58.6 & 75.4 & 79.4 \\
\hline Ash (\% TS) & 16.7 & 6.3 & 4.4 & 8.6 & 11.7 \\
\hline
\end{tabular}

Table 2a. Kinetics of biogas production of co-digested substrates using Modified Gompertz Model (means \pm relative error)

\begin{tabular}{|c|c|c|c|c|}
\hline & YP+WH & $\mathrm{CP}+\mathrm{WH}$ & $\mathrm{CoP}+\mathrm{WH}$ & PP+WH \\
\hline $\begin{array}{lll}\text { Lag } & \text { Phase, } & \lambda \\
\text { (days) } & & \\
\end{array}$ & $0.17 \pm 0.07$ & $0.01 \pm 0.01$ & $0.14 \pm 0.03$ & 0.00 \\
\hline $\mathrm{Rm}$ (ml/g VS/day) & $82.38 \pm 1.38$ & $45.55 \pm 0.06$ & $66.73 \pm 0.42$ & $61.47 \pm 1.40$ \\
\hline$P$ (ml/g VS) & $443.65 \pm 1.27$ & $336.74 \pm 11.17$ & $426.81 \pm 10.39$ & $420.46 \pm 14.41$ \\
\hline T80 (days) & $6.0 \pm 0.00$ & $8.4 \pm 0.30$ & $6.82 \pm 0.04$ & $7.42 \pm 0.11$ \\
\hline $\mathbf{R}^{2}$ & 0.9289 & 0.9441 & 0.9476 & 0.9586 \\
\hline $\begin{array}{l}\text { Measured Biogas } \\
\text { Yield (ml/g VS) }\end{array}$ & $469.28 \pm 0.89$ & $355.61 \pm 13.13$ & $444.81 \pm 9.25$ & $439.74 \pm 14.36$ \\
\hline $\begin{array}{l}\text { Simulated Biogas } \\
\text { Yield (ml/g VS) }\end{array}$ & $443.59 \pm 1.26$ & $336.14 \pm 11.01$ & $426.55 \pm 10.35$ & $420.05 \pm 14.36$ \\
\hline$\%$ Difference & $5.48 \pm 0.09$ & $5.47 \pm 0.39$ & $4.11 \pm 0.33$ & $4.48 \pm 0.03$ \\
\hline
\end{tabular}

Table $2 \mathrm{~b}$. Kinetics of biogas production of mono-digested substrates using Modified Gompertz Model (means \pm relative error)

\begin{tabular}{|ll|lll|}
\hline \multicolumn{1}{|c|}{ YP } & CP & CoP & PP \\
\hline Lag Phase, $\lambda$ (days) & $0.61 \pm 0.08$ & 0.00 & $0.30 \pm 0.01$ & 0.00 \\
\hline $\mathbf{R m ~ ( m l / g ~ V S / d a y ) ~}$ & $135.3 \pm 2.12$ & $87.91 \pm 0.51$ & $68.73 \pm 3.13$ & $62.96 \pm 1.26$ \\
\hline $\mathbf{P}$ (ml/g VS) & $586.76 \pm 20.93$ & $406.36 \pm 5.44$ & $459.33 \pm 7.04$ & $454.68 \pm 6.70$ \\
\hline T80 (days) & $5.25 \pm 0.05$ & $6.25 \pm 0.05$ & $6.84 \pm 0.17$ & 7.44 \\
\hline $\mathbf{R}^{2}$ & 0.9539 & 0.9704 & 0.9749 & 0.9702 \\
\hline $\mathbf{R}^{2}$ Adj. & 0.9394 & 0.9605 & 0.9666 & 0.9603 \\
\hline RMSE & $0.2023 \pm 0.01$ & 0.2268 & 0.0773 & $0.1234 \pm 0.01$ \\
\hline $\begin{array}{l}\text { Measured Biogas } \\
\text { Yield (ml/g VS) }\end{array}$ & $621.42 \pm 20.58$ & $437.35 \pm 5.37$ & $471.66 \pm 7.46$ & $469.57 \pm 7.76$ \\
\hline $\begin{array}{l}\text { Simulated Biogas } \\
\text { Yield (ml/g VS) }\end{array}$ & $586.76 \pm 20.93$ & $406.35 \pm 5.44$ & $458.90 \pm 7.14$ & $454.02 \pm 6.72$ \\
\hline$\%$ Difference & $5.59 \pm 0.24$ & $7.09 \pm 0.10$ & $2.70 \pm 0.03$ & $3.31 \pm 0.17$ \\
\hline
\end{tabular}


Figure 1. Daily and cumulative biogas production curves of co-digested food waste (means with error bars indicating duplicate values).

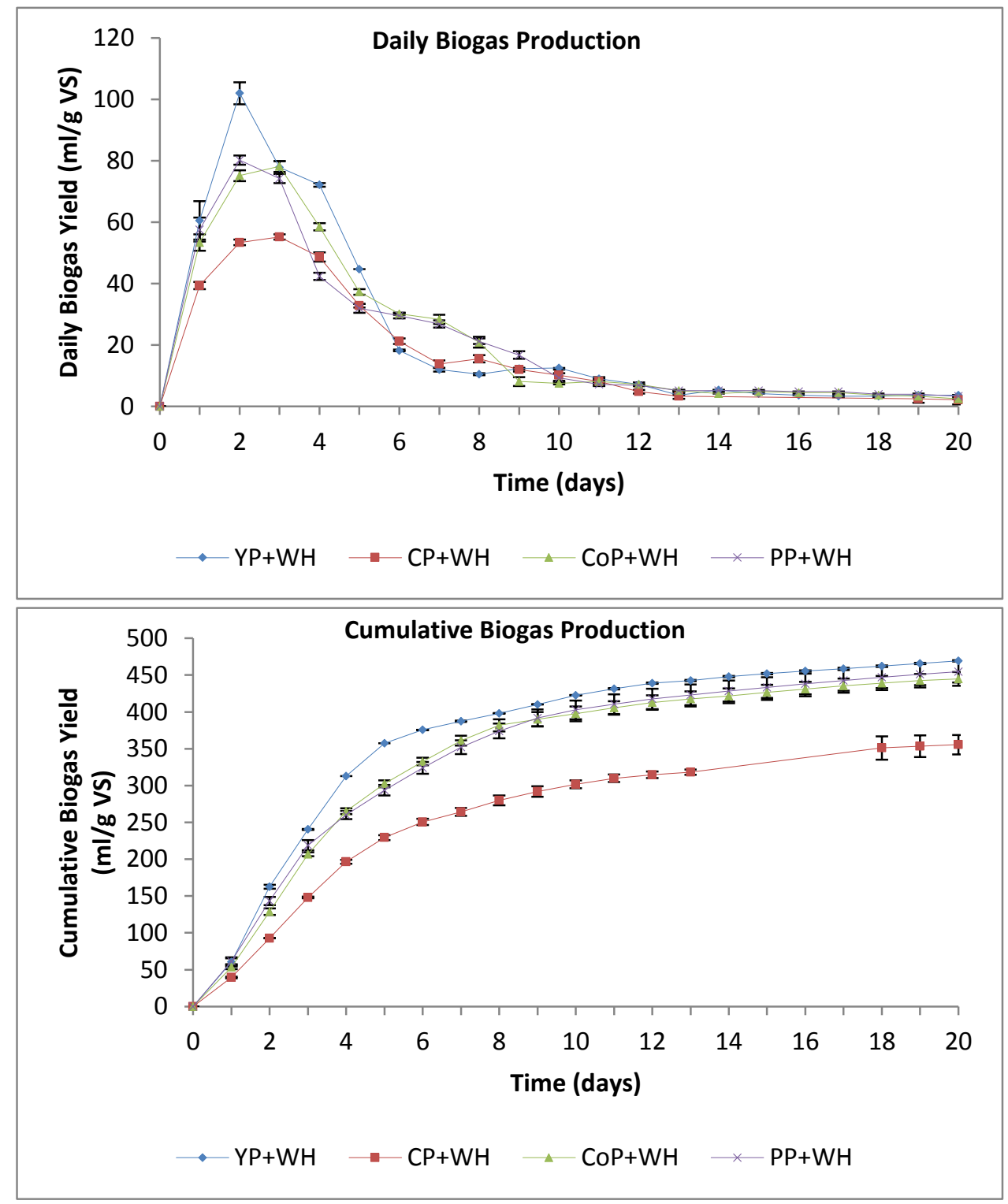


Figure 2. Biogas composition of co-digested food waste (max propane measuring limit at $5 \%$ ).

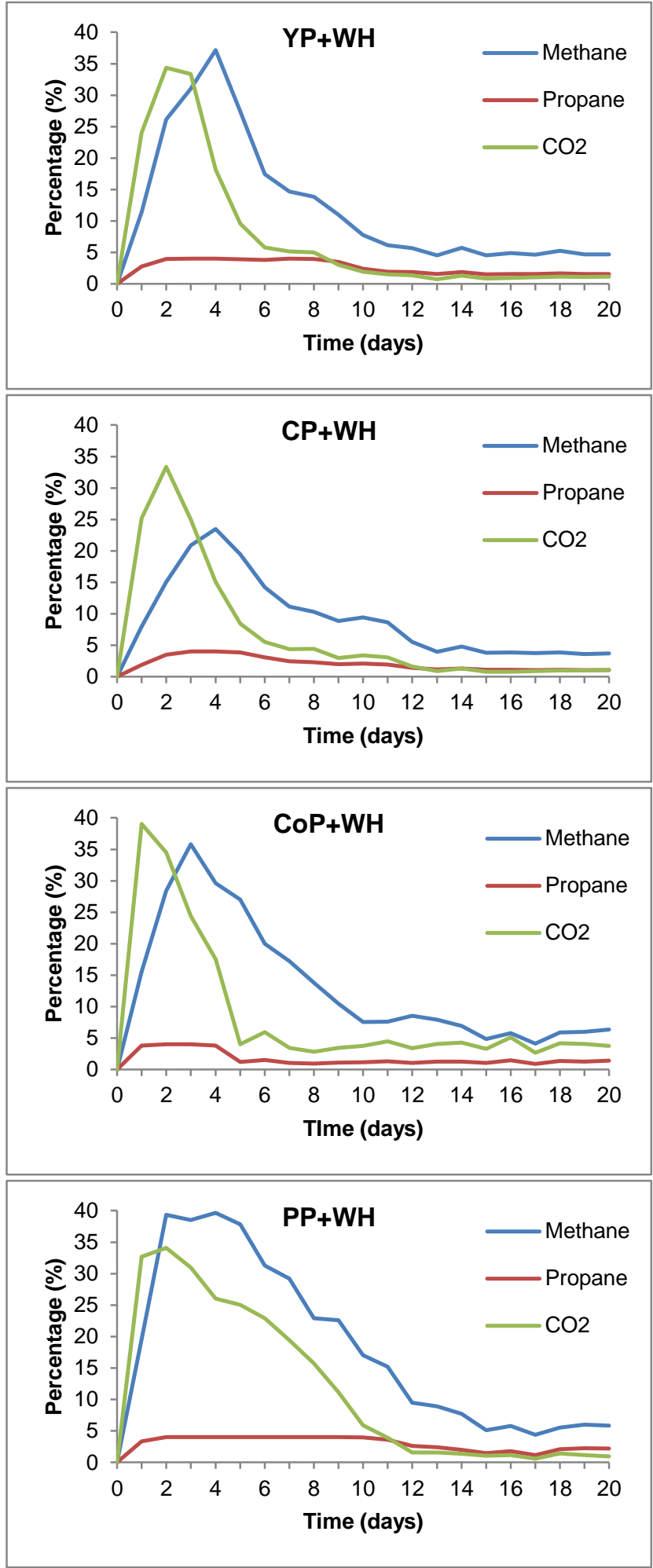


Figure 3. Daily and cumulative biogas production curves of mono-digested food waste (means with error bars indicating duplicate values).
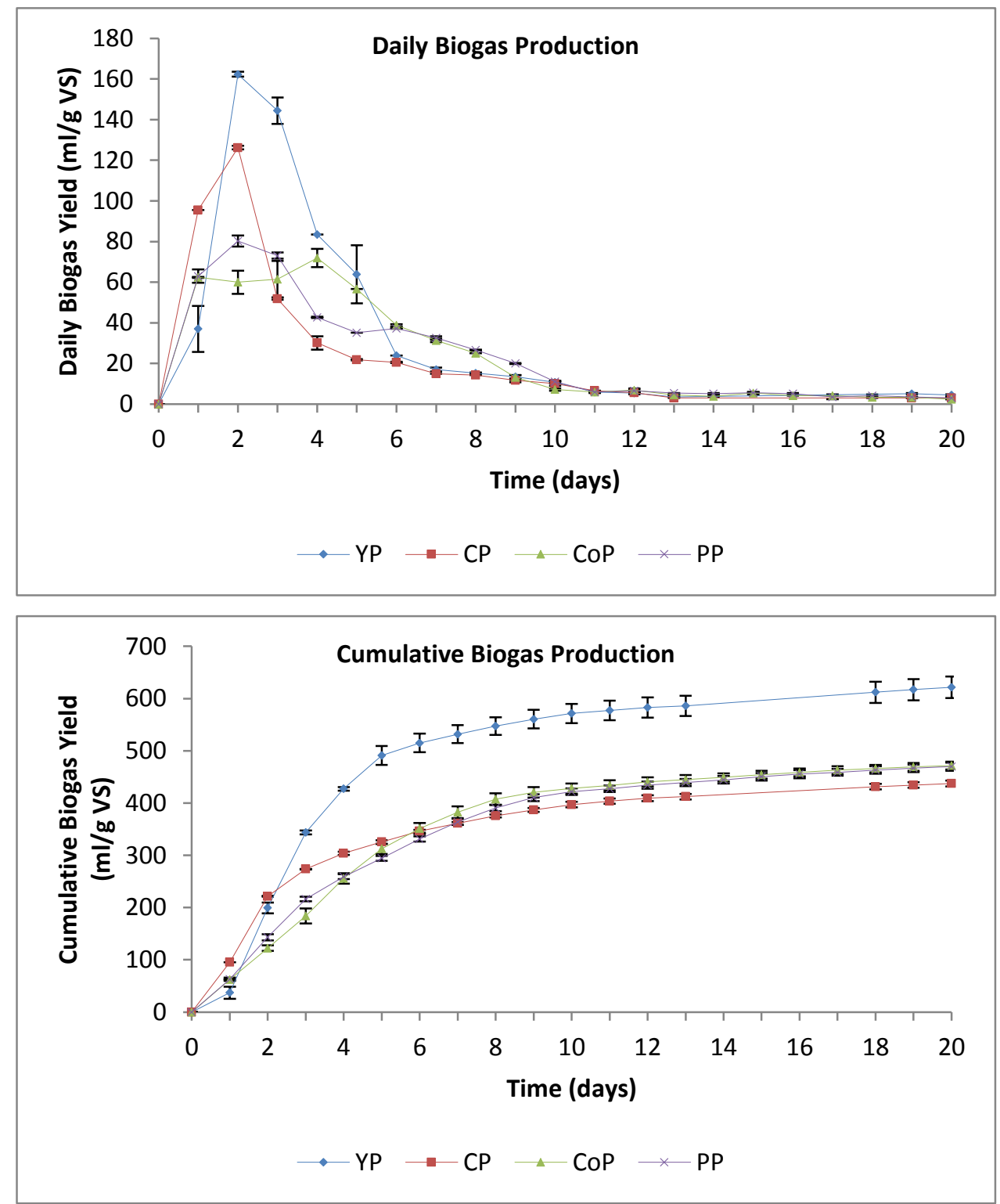


\section{Biogas Production Potential of Co-digested Food Waste and Water Hyacinth common to the Niger Delta}

Longjan, Gurumwal George* Dehouche, Zahir

College of Engineering, Design and Physical Sciences, Brunel University London, Uxbridge, UB8 3PH, UK

Tel: +44 7552141851

Email: gurumwal.longjan.1@my.brunel.ac.uk

\section{Acknowledgement}

I would like to appreciate Community by Design for providing access to their Anaerobic Digester, and specifically Rokiah Yaman for providing technical expertise and a constant source of inoculum for the bio-methane tests. 


\section{Biogas Production Potential of Co-digested Food Waste and Water Hyacinth common to the Niger Delta}

Yam Peel (YP), Cassava Peel (CP), Cocoyam Peel (CoP) and Plantain Peel (PP) are common food wastes of the Niger Delta region. Anaerobic Digestion (AD) of these wastes with Water Hyacinth (WH) presents a viable way of both providing renewable energy and cleaning up the environment. Anaerobic digestion tests were carried out on the food wastes and WH to determine their biogas potentials. The experiments were carried out under mesophilic conditions at $\left(37 \pm 1^{\circ} \mathrm{C}\right)$ over a period of 20 days and the tests were replicated to give an indication of repeatability. The results showed that $\mathrm{YP}+\mathrm{WH}, \mathrm{CP}+\mathrm{WH}, \mathrm{CoP}+\mathrm{WH}$ and $\mathrm{PP}+\mathrm{WH}$ had specific biogas yields of $0.42,0.29,0.39$, and $0.38 \mathrm{~m}^{3} / \mathrm{kg}$ Volatile Solid (VS) respectively. The yields represented $76 \%, 48 \%, 70 \%$ and $69 \%$ of their respective theoretical values. Co-digesting the food wastes with WH in the VS ratio of 2:1 reduced the biogas yields of $\mathrm{YP}, \mathrm{CP}, \mathrm{CoP}$ and $\mathrm{PP}$ by $16 \%, 22 \%, 7 \%$ and $7 \%$ respectively. The drop in gas production was due to indigestible complex molecules in the $\mathrm{WH}$ co-substrate. The results indicate that common food wastes in the Niger Delta can be used as feedstock for AD, but co-digesting with $\mathrm{WH}$ reduces the biogas yield.

Keywords: anaerobic digestion, biogas, food waste, Niger Delta, Water Hyacinth.

Word Count: 6,112 


\section{Introduction}

Nigeria is one of the largest producers of crude oil. Despite the abundant oil reserve, the country's energy sector struggles to meet energy demands. $52 \%$ of the population have no access to electricity while $75 \%$ of the population utilise traditional biomass like firewood for cooking [1]. The use of such traditional fuels is the major factor leading to an increase in desertification and change in the country's vegetation [2]. Harnessing renewable energy in Nigeria would help in addressing the energy shortfall. The clean energy would also mitigate environmental degradation from burning of traditional fuels.

A region that urgently requires the adoption of such renewable technologies is the Niger Delta region. The area is home to Nigeria's crude oil deposits and has suffered environmental degradation from resource extraction, oil spills and gas flaring. In addition to pollution from the oil and gas sector, the Niger Delta, which is located on a delta has suffered from the infestation of the aquatic weed water hyacinth. Its presence has led to negative effects on the socio-economic activities of the region. Another adverse effect of the watery terrain of the region is the difficulty it causes in extending the national power grid to the remote Niger Delta communities. The consequence is a lack of adequate power in the region that further promotes the use of firewood, enhancing deforestation. The absence of electricity also forces local households to utilise fuel based electric generators that further pollute the atmosphere with noxious greenhouse gases. Another notable source of pollution in the region is communal waste. This comes from the indiscriminate disposal of domestic and household wastes. The lack of sufficient policies on waste management has led to unsanctioned disposal methods including dumping of waste into the local water bodies and open air burning of household waste. 
These energy utilising and environmental degrading activities in the Niger Delta have the potential to deprive future generations of energy sources and healthy living conditions. Studies have shown that improved energy improves security, health and education and reduces poverty. There is a positive link between rural electrification, rural development, poverty alleviation and reduced environmental degradation [3].

Considering the energy and environmental challenges of the Niger Delta, a suitable clean energy technology for the region is anaerobic digestion (AD). The process involves the degradation of organic materials by microorganisms in oxygen-free environments for the production of biogas. The process consists of four main stages namely: hydrolysis, acidogenesis, acetogenesis and methanogenesis. In each of these stages, the original organic material is converted into intermediaries like organic acids and hydrogen, which eventually produce the biofuel methane. Biofuels produced from the anaerobic digestion of organic wastes addresses some of the environmental degradation issues of the Niger Delta. The potential feedstock for the digestion process would consists of both the organic fraction of communal wastes and the abundant problematic water hyacinth. Utilising water hyacinth as a feedstock would aid in mitigating its proliferation in the region. Furthermore the soil, water and atmosphere will benefit from the reduction in burying, dumping and burning of waste respectively. For regions that have poor energy infrastructure, biogas from $\mathrm{AD}$ can reduce the dependence on fossil fuels and help mitigate deforestation while improving the livelihood of rural populations [4]. Biogas from waste has been shown to reduce poverty and improve on the economic development in developing countries [5].

There has been extensive research in the biogas potentials of feedstocks that are common to the developed countries, such as energy crops, industrial waste and sewage sludge. In contrast there has been limited research on the biogas potentials of exotic 
food wastes common to rural Nigerian communities. This may be a result of laboratories in developing countries having almost no access to advanced gas measuring equipment, which limits research aimed at improving local biogas production [6].

Furthermore the FAOSTAT [7] database indicates that Nigeria is the world's largest producer of Yam (Dioscorea rotundata Poir.), Cassava (Manihot esculenta Crantz), Cocoyam (Colocasia esculenta (L.) Schott) at 40,500,000, 53,000,000 and $3,500,000$ tonnes respectively. This is in addition to producing some of the highest volumes of Plantain (Musa paradisiaca L.) at 2,780,000 tonnes. These four foods are the most commonly consumed in the Niger Delta based on consumption patterns [8], household expenditures [9] and farming practices [10]. These foods will undoubtedly produce high amounts of food waste, including Yam Peel (YP), Cassava Peel (CP), Cocoyam Peel (CoP) and Plantain Peel (PP) that can be used as feedstock for the anaerobic digestion process. Each of these potential feedstock will need to be characterised to determine their suitability as $\mathrm{AD}$ feedstock [11]. Additionally the distribution of protein, fats and carbohydrates in feedstock is important for assessing its fitness for the $\mathrm{AD}$ process [12]. Furthermore feedstock composition can be used to determine the retention time of a digester based on the various digestibility rates of different nutrients. Simple sugars, volatile fatty acids and alcohols are digested in hours, proteins and lipids in days while cellulose takes weeks to anaerobically degrade [13]. If data on the feedstock is available, it can be used for an initial evaluation of the suitability of the feedstock for digestion. This creates a need for the characterisation of Niger Delta food wastes and water hyacinth for the benefit of researchers, policy advisers and potential AD investors.

The current literature on the co-digestion of water hyacinth focuses on its synergistic effects on animal manure. There is limited data on the effects of co-digesting 
the plant with food waste. This study will evaluate the biogas potentials of common food wastes in the Niger Delta. The focus will be on their characterisation and biogas potential from co-digestion with water hyacinth. The research approach is experimental and uses conventional research methods in a new area of investigation.

\section{Materials and methods}

\subsection{Sample Collection}

Yam, Cassava, Cocoyam and Plantain were selected as the sources of food waste based on consumption patterns in the Niger Delta. They were sourced from the region and transported to Brunel University in preparation for the experiments. The wastes from the yam, cassava and cocoyam were obtained by using a kitchen knife to cut off thin slices of their outer coats. The plantains waste is obtained by using a kitchen knife to make a $5 \mathrm{~mm}$ insertion into the top of the plantain and making a cut to the bottom. The outer coat is then cleanly pulled off by hand. Their respective food wastes are Yam Peel (YP), Cassava Peel (CP), Cocoyam Peel (CoP) and Plantain Peel (PP). Sourcing the water hyacinth from the Niger Delta was not possible due to EU and UK regulations concerning water hyacinth, hence the fresh water hyacinth was obtained from Anglo Aquatic Plant Enfield, an agricultural nursery that specialises in aquatic plants.

The peels and $\mathrm{WH}$ were decontaminated by rinsing with deionized water to remove dust, coarse particles and other extraneous contaminants that could adversely affect the test results. Sub-samples of the substrates were then sent to NRM Laboratories Bracknell, where their nutrient characteristics were determined using standard analytical tests for total and volatile solids, ash, crude protein, fibre and oils. The results are presented in Table 1. 


\subsection{Waste Content and Specific Waste Index}

The waste content of each food sample was determined by extracting and weighing the inedible part of the food and determining its proportion in the weight of the whole food. The weight of the foods and wastes were measured using an Adam Equipment PGL 2002 Analytical Balance. The tests were performed in triplicates to improve precision. The organic waste content was determined as the proportion of the food waste that is organic in nature. The results were used to calculate the Specific Waste Index of the various foods which is the ratio of the weight of their individual wastes to that of their respective consumable parts [14]. The equation is shown in (1).

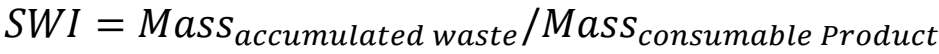

\subsection{Substrate preparation}

The sample peels were cut into $2 \mathrm{~cm}$ pieces and then heat dried in a Thermo Scientific box furnace at $80^{\circ} \mathrm{C}$ for 24 hours in order to stabilize the tissue and stop enzymatic reactions. The procedure was based on Campbell and Plank [15] who observed that plant samples dried below $80{ }^{\circ} \mathrm{C}$ might not lose all moisture and above that temperature may lead to thermal decomposition and reduce the dry weight of the sample. After drying, the various peels were individually ground in a Waring WSG30 high-speed mill into fine powder and sieved through a mesh of $0.5 \mathrm{~mm}$. The milling process also homogenised the samples.

\section{$2.4 \quad$ Inoculum}

The inoculum/active biomass was obtained from the $2 \mathrm{~m}^{3}$ Anaerobic Digestion plant at Camley Street Natural Park, London. The digester has been running for two years and is fed catering food wastes consisting of fruit and vegetable peels, eggshells, coffee 
grounds, chips and bacon from local canteens.

\subsection{Inoculum Preparation}

The inoculum was sieved through a $0.5 \mathrm{~mm}$ mesh in order to remove coarse particulates and thus increase the Volatile Solid (VS) to Total Solid (TS) ratio. The inoculum had a TS content of $5 \%$ and a VS content of $3 \%$, indicating a VS/TS of $62 \%$. These values met up to the VDI 4630 [22] requirement of the inoculum having at least 50\% VS/TS.

$0.5 \mathrm{~kg}$ of the inoculum was measured into each of nine 0.51 bioreactor vessels, sealed and then sparged with nitrogen to create an anaerobic environment. The vessels were then placed in a water bath set to $\left(37 \pm 1^{\circ} \mathrm{C}\right)$. The setup was allowed to run for seven days in order to degas the microbes, thus reducing the biogas contribution of the inoculum by means of a "hunger phase". The process also allowed the microbes to adapt to the new environmental conditions.

\subsection{Anaerobic Digestion Batch Tests}

The anaerobic digestion tests were performed in line with the guidelines set by VDI 4630 [22] for standardized fermentation test. Nine bioreactor vessels in a heating bath were used to perform the AD tests in duplicates. The vessels were distributed between various batches of the tests to provide randomisation. Prior to testing, the vessels were washed and disinfected with isopropanol to eliminate any microbial activity that might contaminate the process.

In each test batch, there were four pairs of vessels which each received $8.4\left(10^{-3}\right.$ $\mathrm{kg}$ ) VS of substrate. In the case of anaerobic co-digestion, a C/N (Carbon to Nitrogen ratio) of 20-30 was not used for the feedstock due to the recalcitrant nature of the water hyacinth co-substrate. A high amount of the Carbon in the plant is locked in lignocellulosic molecules, which are unavailable to the AD microbes. Hence any 
digestion projection using such Carbon content will not provide a realistic outcome. For this study, the $8.4\left(10^{-3} \mathrm{~kg}\right)$ VS allocation for feedstock was divided in the ratio $2: 1$ between the food waste and water hyacinth. The pre-treated inoculum was measured into $0.5 \mathrm{~kg}$ batches and then added to each of the eight vessels containing waste samples, while the ninth vessel consisted of only $0.5 \mathrm{~kg}$ of inoculum and served as the blank test that provided the gas contribution of the inoculum. All vessels were thoroughly mixed to maximise contact between the substrates and the microbes.

The vessels were then sealed and sparged with Nitrogen to create an anaerobic environment. The nine reactors were then placed in a shaking water bath at the mesophilic temperature of $\left(37 \pm 1{ }^{\circ} \mathrm{C}\right)$ and shaking rate of 100 strokes per minute for agitation.

An inline biogas analyser was connected to the reactor vessels and used to determine the percentage of methane, propane and carbon dioxide in the biogas every 15 minutes during the BMP test period. Biogas production was measured by gas collection in inverted graduated $500 \mathrm{ml}$ cylinders, while readings were taken twice daily for the first 3-5 days when there was rapid gas production. Subsequently the readings were taken daily to make the course of gas formation recognisable. Cumulative flow graphs were drawn from the recorded data to determine the gas production curves. The retention time was 20 days for each batch. That time was sufficient for the daily gas production rate to drop to less than $1 \%$ of the cumulative gas produced up to that moment, which is in line with VDI 4630 guidelines. The Specific Biogas Yield (SBY) of the food wastes were determined by deducting the biogas contribution of the inoculum from the cumulative biogas production of the food wastes. 


\section{Results and Discussion}

\subsection{Food Waste Content}

The Specific Waste Index (SWI) of the four food samples ranged from $0.3-0.5$ with an average value of 0.4 . The results indicated that plantain had the highest SWI of 0.5 while cassava had the lowest value at 0.3 . The average waste content of the four food items is $26 \%$ while their average organic waste content is $6 \%$. Plantain had the highest waste content of $34 \%$ of which just $14 \%$ of that amount was organic in nature. Yam had the second highest waste content of $25 \%$ of which $34 \%$ was organic in nature. The lowest amount of waste was from cassava at $20 \%$.

The statistical analysis of the waste contents was performed using the nonparametric Kruskal-Wallis test. The results indicated that there was a significant difference $(p<0.05)$ between the amounts of waste produced from the four foods. The non-parametric post-hoc Dunn's test was used to identify which samples were significantly different from each other. The results identified only cassava and plantain as having a significant difference between their waste contents.

Yam and cassava have high variations in waste content due to the differences in the sizes of their individual tubers and the variation in the amount of edible components that are cut off with the peels. Plantains have the least variations in waste content as a result of the similar sizes of plantains. Additionally the peels of plantains are easily removed without any of the edible parts of the plantain. The SWI values for the three ground tubers of yam, cassava and cocoyam are close to the values for another ground crop, potato at $0.3-0.5$, obtained by Russ and Meyer-Pittroff [14]. The results show that foods can have high waste contents but the wastes will consist of low organic proportions. 
Foods with high SWI are ideal as sources of potential feedstock that will be considered in the anaerobic digestion chain. If SWI is the only factor, plantain is the ideal feedstock. However, when considering the organic content of the food waste, yam becomes the ideal choice. The implication is that both factors of total waste and organic waste content have to be considered when selecting an appropriate food for its waste as AD feedstock.

\subsection{Food Waste and Water Hyacinth Characterization}

Results from the characterisation of the food waste revealed that the Total Solid content varied widely between samples. The values ranged from $7.2 \%$ for water hyacinth to $36.6 \%$ for yam peels with an average value of $22.6 \%$. Results of the VS/TS analysis showed that plantain peels and water hyacinth had the lowest values at $88.3 \%$ while cassava peels had the highest value at $95.6 \%$. Crude protein values ranged from $7.4 \%$ $\mathrm{VS}^{-1}$ for plantain peels to $20 \% \mathrm{VS}^{-1}$ for water hyacinth while crude fibre content ranged from $7.0 \% \mathrm{VS}^{-1}$ for yam peels to $20 \% \mathrm{VS}^{-1}$ for water hyacinth. The oil contents of the samples were all below $5.1 \% \mathrm{VS}^{-1}$ with the exception of cassava peels, which had a relatively high value of $24.6 \% \mathrm{VS}^{-1}$ due to the wax used in its preservation process [18]. The Nitrogen Free Extracts (NFE) made up the highest nutrient proportion of the volatile solids in all the samples. The value was as high as $82.2 \% \mathrm{VS}^{-1}$ for yam peels to $55.0 \% \mathrm{VS}^{-1}$ for water hyacinth. Water hyacinth had the highest ash contents at $16.7 \%$ due to its roots having a high affinity for accumulation of metals [19].

The TS of the samples were within the range of energy crops of $15-40 \%$ as reported by Al Seadi et al. [13]. Low TS feedstock increase digester volume with low nutrient content while those with high TS require additional water when digested [12]. The VS/TS results of YP, CP and CoP were above the range of VS/TS for energy crops 
and plant wastes of $70-90 \%$ as reported by Al Seadi et al. [13] and Neureiter [16]. Feedstocks with VS/TS below $60 \%$ are not suitable for the AD process [12].

Excessive amounts of any of the nutrients can have detrimental effects on the AD process. High amounts of protein can lead to high ammonia concentrations while high fibre content can cause foaming and lignin incrustation in digesters. High oil content can lead to longer retention times and accumulation of fatty acids.

\subsection{Theoretical Bio-methane Potential}

The results of the theoretical Bio-Methane Potential analysis showed a narrow range of $549.2-619.0 \mathrm{~m}^{3} / \mathrm{g}$ VS for biogas yields. The methane content varied between $52.0-$ $57.4 \%$. The biogas potentials are within the range of biogas yields of corn, barley, crude glycerine and wheat grains as reported in NNFCC [20]. CP had the highest biogas and methane potential at $619.0 \mathrm{~m}^{3} / \mathrm{g} \mathrm{VS}$ and $57.4 \%$ respectively. While the lowest biogas and methane potentials were from YP at $549.2 \mathrm{~m}^{3} / \mathrm{g}$ VS and $52 \%$ respectively.

When considering the biogas potentials of the Fresh Weight $(\mathrm{FW})$ of the samples, there was a high variation in potential yield, ranging from $33.3-188.4 \mathrm{~m}^{3} / \mathrm{t}$ FW with an average potential of $119.0 \mathrm{~m}^{3} / \mathrm{t} \mathrm{FW}$. YP had the highest potential at 188.4 $\mathrm{m}^{3} / \mathrm{t} \mathrm{FW}$ followed by CP at $173.3 \mathrm{~m}^{3} / \mathrm{t} \mathrm{FW}$. Next was CoP at $123.6 \mathrm{~m}^{3} /$ tonne and lastly PP with the least potential at $76.4 \mathrm{~m}^{3} /$ tonne.

The theoretical biogas yields on a VS basis present the biogas potential of the feedstock in respect of the organic dry matter content of the sample. The yield on a fresh weight basis presents the theoretical results of yield from the wet weight of the sample. CP had the highest biogas potential per mass of VS and the highest methane content. When considering the wet weight, it has the second highest yield. Its high moisture content of $70.7 \%$ would cause a low nutrient concentration in a digester leading to lower energy output. YP had the highest fresh weight biogas potential while 
PP had the least potential at $76.4 \mathrm{~m}^{3} /$ tonne. There was a direct correlation between moisture content and low wet weight biogas yields. The higher the moisture content, the lower the wet weight biogas yields.

The range of results for biogas yields on a VS basis corresponds to a wide variety of feedstock found in literature. Feedstock with similar yields include vegetable waste, potato waste, food waste, fruit waste, slaughterhouse waste and household waste as reported by Deublein and Steinhauser [21]. This signifies that the theoretical biogas potentials of Niger Delta food wastes are within the range of values from conventional AD substrates. This suggests their suitability as candidates for AD feedstock. Their actual biogas yields will be lower than their theoretical values due to the presence of non-degradable material. Additionally microbes consume 3-10\% of the substrates for their growth [22].

Comparing the study's wet weight biogas potentials with results reported in Korres et al. [23], the theoretical yield of $\mathrm{WH}$ at $33.3 \mathrm{~m}^{3} /$ tonne was higher than the reported $14.7 \mathrm{~m}^{3} /$ tonne. Yam and cassava peel yields were within the range of values of crops such as barley, rye, sugar beet and rice straw, which ranged from 156.6 - 266.6 $\mathrm{m}^{3} /$ tonne.

The Spearman's Rank Order Correlation was used to test if there was a correlation between the various characteristics of the food wastes and their biogas yields. The results showed a perfect correlation between the FW biogas yields and the TS and VS content. There was also a strong relationship between the yields and the VS/TS ranking. This implies that the TS or VS content of various feedstocks in a group can be used to determine which feedstock will produce more or less biogas than other members of the group. For the biogas yield on VS basis, there was a moderate relationship with the TS and VS content. Methane content had a strong correlation with 
moisture and oil content of the feedstock. The relationship is not perfect, so should be used cautiously when estimating which feedstocks have higher methane contents.

\subsection{Biogas Production of Co-digested Food Waste}

\subsubsection{Biogas Yields of Co-Digested Substrates}

The results from the BMP tests showed that $\mathrm{YP}+\mathrm{WH}$ had the highest biogas yield at $419 \mathrm{ml} / \mathrm{g}$ VS. Next were CoP+WH and PP+WH at $387.53 \mathrm{ml} / \mathrm{g}$ VS and $382.46 \mathrm{ml} / \mathrm{g} \mathrm{VS}$ respectively. $\mathrm{CP}+\mathrm{WH}$ had the lowest yield at $285.21 \mathrm{ml} / \mathrm{g}$ VS. The low yield of the $\mathrm{CP}+\mathrm{WH}$ was expected because studies had shown that the cyanide content of the cassava peels was detrimental to the AD microbes especially the methanogens [24-26].

The results of the daily gas production showed that biogas production peaked within the first three days for all the samples. The peak gas productions for the YP+WH and $\mathrm{PP}+\mathrm{WH}$ were on the second day, while for the $\mathrm{CoP}+\mathrm{WH}$ and $\mathrm{CP}+\mathrm{WH}$ it was on the third day. This implied a rapid consumption of the readily available nutrients by the microorganisms and subsequent rapid conversion of the intermediate products to final products. By the fourth day, gas production was in the retardation phase. The gas production curves are shown in Figure 1.

Most of the biogas yields were obtained within the first six days, with $\mathrm{YP}+\mathrm{WH}$, $\mathrm{CP}+\mathrm{WH}, \mathrm{CoP}+\mathrm{WH}$ and $\mathrm{PP}+\mathrm{WH}$ producing $80 \%, 70 \%, 75 \%$ and $71 \%$ of their total production by the sixth day.

The Biodegradability (BD) of the substrates, which is the percentage of the theoretical to the measured biogas yields [27], were determined. The theoretical yields were calculated using the Baserga model, which uses the nutrient composition of each substrate to calculate their theoretical biogas potential. The model assumes that all nutrients are converted to biogas. $\mathrm{YP}+\mathrm{WH}$ had the highest biodegradability at $76.1 \%$. 
Next were CoP+WH and $\mathrm{PP}+\mathrm{WH}$ with values of $70.2 \%$ and $68.5 \%$ respectively. Least biodegradable was $\mathrm{CP}+\mathrm{WH}$, which had a low value of $47.9 \%$.

The variation between theoretical and actual values is occasioned by the presence of complex nutrients in plant-based feedstock, inhibitory factors and the consumption of nutrients by microbes for their growth. Drosg et al. [11] stated that plant based feedstock attained $50-70 \%$ of their theoretical values when anaerobically digested. The results show that $\mathrm{YP}+\mathrm{WH}, \mathrm{PP}+\mathrm{WH}$ and $\mathrm{CoP}+\mathrm{WH}$ were either within or surpassed the range while the biodegradability of $\mathrm{CP}+\mathrm{WH}$ was below the lower limit.

Despite $\mathrm{CP}+\mathrm{WH}$ having the highest theoretical value of biogas production, the actual digestion produced a very low amount of biogas. This is caused by the cyanide content of the cassava peels, which adversely affects the AD microbes [25-26]. A method was developed by Cuzin and Labat [24] to reduce the cyanide levels during the AD of cassava peels, to a non-inhibitory concentration. The method utilised cyanide detoxification enzymes in a plug flow digester to reduce the cyanide concentration. Cumbana et al. [28] used a "Wetting Method" to also reduce the cyanide content of the plant. The process involved mixing the cassava with water and spreading it out to dry in a thin layer. Bradbury and Denton [29] modified an earlier wetting method and lowered the time taken to reduce the cyanide content to two hours, reducing the original method by three fold. This was accomplished by drying the mixture in the sun rather than the shade. Such methods could improve the gas production from the anaerobic digestion and co-digestion of cassava peels.

The difference between the measured biogas and the theoretical yield may be reduced by chemical pre-treatment of the substrates. This would break down the lignin and other complex molecules into shorter chains that can be readily consumed by the microbes. Studies by Patil et al. [30], Cheng et al. [17], Gao et al. [31] and Cheng et al. 
[32] showed that using chemicals to pre-treat water hyacinth reduced lignin and broke down crystalline cellulose. In each of the studies, biogas production increased after pretreatment. In order to reduce the difference between measured and theoretical values of the samples, chemical pre-treatment and reduction of inhibiting substances from the feedstock need to be implemented.

The $\mathrm{pH}$ values of the BMP tests over the 20-day period varied between 7 and 8 . In all tests the $\mathrm{pH}$ values fell within the first two days, indicating the presence of organic acids. After the second day, there was a steady increase in $\mathrm{pH}$ values, and from the eighth day, the values remained steady. The final $\mathrm{pH}$ values for the samples were between 7.75 and 7.93 , indicating that there was no accumulation of excess organic acids. This implied that the substrate to inoculum ratio of 1:2 VS was sufficient enough to prevent any acid build up.

\subsubsection{Kinetics}

The cumulative biogas production curves were fitted to the Modified Gompertz Model shown in (2) using non-linear regression:

$M=P \times \exp \left\{-\exp \left[\frac{R_{m} \times e}{P}(\lambda-t)+1\right]\right\}$

Where $M$ is the Cumulative Biogas Production ( $\mathrm{ml} / \mathrm{g} \mathrm{VS}$ ), $\lambda$ is the Lag Phase (days), $t$ is the Digestion Period (days), $R_{m}$ is the Maximum Biogas Production Rate $(\mathrm{ml} / \mathrm{g}$ VS/day), $P$ is the Biogas Production Potential (ml/g VS) and $e$ is 2.718282.

The model gives the cumulative biogas production from batch digesters. The results are presented in Tables $2 \mathrm{a}$ and $2 \mathrm{~b}$. In all results, the measured biogas was more than the simulated values. The respective simulated biogas values of $\mathrm{YP}+\mathrm{WH}, \mathrm{CP}+\mathrm{WH}$, $\mathrm{CoP}+\mathrm{WH}$ and $\mathrm{PP}+\mathrm{WH}$ were $94.5 \%, 94.5 \% 95.9 \%, 95.5 \%$ of their measured values. 
The model curves had a very close fit to the gas production curves indicating the measured biogas yields are in agreement with the simulated values. This is confirmed by the high values of $\mathrm{R}^{2}$ ranging from 0.9289 for $\mathrm{YP}+\mathrm{WH}$ to 0.9586 for $\mathrm{PP}+\mathrm{WH}$. The conclusion is that these results can be used to validate the Modified Gompertz Model.

The lag phase, which is the minimum time required for the microorganisms to adapt to the environment and commence gas production was less than five hours in all tests. This is because the inoculum had been acclimatised to the bioreactor environment for a week prior to the BMP test. The process degassed the microbes and created a hunger phase. This led to an early consumption of the readily available components of the introduced substrate. The microbial activity led to instant gas productions thereby reducing the lag phase.

The T80 or Technical Digestion Time is the time needed to produce $80 \%$ of the total gas production [33]. For the various substrates, YP+WH had the shortest T80 period of 6 days. This indicates a rapid consumption and conversion of available nutrients. The longest T80 was for the $\mathrm{CP}+\mathrm{WH}$ at 8.4 days. This could have resulted from the toxic effect of cyanide on the microbes, leading to a reduction in the microbial population. This would cause the remaining microbes to take longer periods to consume the available nutrients. The $\mathrm{T} 80$ values for the $\mathrm{CoP}+\mathrm{WH}$ and $\mathrm{PP}+\mathrm{WH}$ were 6.8 days and 7.4 days respectively. The T80 period can be used as a benchmark for the retention period or Hydraulic Retention Time of an AD process.

\subsubsection{Biogas composition}

The methane and carbon dioxide content were automatically analysed by an inline NonDispersive Infra Red (NDIR) biogas sensor. The sampling period was every 15 minutes. The average daily results are presented in Figure 2. For all the samples, the initial biogas production consisted mainly of carbon dioxide with a lower amount of methane. 
The switch from a higher carbon dioxide content to a higher methane content occurred on the second day for $\mathrm{CoP}+\mathrm{WH}$ and $\mathrm{PP}+\mathrm{WH}$ and on the third day for both $\mathrm{YP}+\mathrm{WH}$ and $\mathrm{CP}+\mathrm{WH}$. The highest average daily methane concentrations for $\mathrm{YP}+\mathrm{WH}, \mathrm{CP}+\mathrm{WH}$, $\mathrm{CoP}+\mathrm{WH}$ and $\mathrm{PP}+\mathrm{WH}$ were $37.2,23.5,37.8$ and $39.7 \%$ respectively. The $\mathrm{CoP}+\mathrm{WH}$ was the first to attain its maximum methane concentration by the third day, while the remaining three samples each attained their maximum values on the fourth day. As explained previously, the very low methane content in the $\mathrm{CP}+\mathrm{WH}$ is a result of the cyanide content which is toxic to microbes especially the methanogens [24-26]. The variation in the biogas composition support the understanding that methane and carbon dioxide content of biogas varies widely between the beginning, middle and end of a BMP batch test. The implication is that a single gas analysis test is not sufficient to determine the methane content of the biogas yield of a feedstock. There needs to be multiple sample points in order to determine the true methane potential of a substrate. The average methane content of the whole duration of the experiment would give a false methane content result because it would include the very low residual methane content at the end of the test. It is more practical to determine the average value for specific time frames. From the biogas yield results, the T80 period corresponds to the peak biogas yields.

Consequently the average methane content was calculated for the T80 period, the remaining retention time (t-T80 days) and the whole duration of the test (t days). The results show that the average methane content during the T80 period is far higher than the other two periods measured. For all the samples, the average methane content for the T80 period was approximately three times the average content for the rest of the retention period (t-T80) and approximately twice the average content for the whole digestion period $(\mathrm{t})$. This leads to a conclusion that it is necessary to take multiple gas 
samples for the biogas analysis during the AD process. It is also necessary to focus on the samples taken during the T80 period, since that could also serve as the retention time in a full scale digester.

\subsubsection{Statistical analysis}

The biogas yield results were evaluated using the Kruskal-Wallis test. The results indicated that there was no significant difference $(\mathrm{p}>0.05)$ between the groups. They were analysed using the SPSS IBM software package.

\subsection{Biogas Potential of Mono-Digested Food Waste}

\subsubsection{Biogas Yields of Mono-Digested Substrates}

YP produced the highest Specific Biogas Yield of $551 \mathrm{ml} / \mathrm{g}$ VS. Next were CoP and PP at $414 \mathrm{ml} / \mathrm{g}$ VS and $412 \mathrm{ml} / \mathrm{g}$ VS respectively. The least yield was from CP at $367 \mathrm{ml} / \mathrm{g}$ VS. As explained in section 3.4, the low biogas yield for the CP was likely a result of the toxic effect of cyanide on microbes, leading to AD inhibition. From the results, the mono-digested substrates are ranked in the same order of highest to lowest biogas yields as their co-digested counterparts in terms of biogas production. The biogas yields had standard deviations of less than $3 \%$ indicating values are very close to the mean.

The biodegradability analysis showed that YP had the highest biodegradability at $100.3 \%$. Next were CoP and PP at $75.1 \%$ and $73.4 \%$ respectively. The lowest was CP at $59.3 \%$. The high biodegradability of YP suggests that there was some synergetic activity in the digester that helped to improve the biogas yield beyond its theoretical values. The high biodegradability is supported by the YP having very high amounts of NFEs at $82.2 \%$ which are soluble carbohydrates easily consumed by microbes. The low biodegradability of $\mathrm{CP}$ results from the presence of cyanide, which adversely affects 
AD microbes. The toxins most likely led to an inefficient consumption of the available nutrients due to incapacitated microbes. This would explain the large variation between the measured and theoretical values, since the theoretical values are based on complete nutrient conversion. The biogas productions of the mono-digested food waste were closer to their theoretical values than the co-digested samples.

The gas production curves are shown in Figure 3. The daily and cumulative biogas production curves showed little variations between the replicates. Gas production for the YP, CP and PP peaked on the second day while for CoP it was on the fourth day.

Similar to the gas production profile of the co-digested substrates, by a quarter of the retention time, most of the gas had been produced by the samples. The percentage of biogas produced by the sixth day for $\mathrm{YP}, \mathrm{CP}, \mathrm{CoP}$ and $\mathrm{PP}$ were $83 \%, 79 \%, 75 \%$ and $71 \%$ respectively. It was an improvement for the $\mathrm{CP}$, whose co-digested counterpart produced $70 \%$ of the total biogas by the same period. The YP also improved from the $80 \%$ of its co-digested counterpart. For the CoP and PP the values were unchanged. The final $\mathrm{pH}$ values for the samples were between 7.09 to 7.96 , with $\mathrm{CP}$ having the lowest final $\mathrm{pH}$ value.

\subsubsection{Effect of water hyacinth on co-digestion}

The Specific Biogas Yields of the food wastes were compared to the yields of their codigested counterparts. For yam, cassava, cocoyam and plantain peels, co-digesting them with water hyacinth in the ratio $2: 1 \mathrm{VS}$, reduced their biogas yields by $16.2,22.3,6.5$ and $7.2 \%$ respectively. The yam and cassava peels had a higher loss in biogas production compared to the cocoyam and plantain peels.

Water hyacinth has recalcitrant nutrients consisting of lignin, cellulose and hemicellulose which AD microbes have difficulty digesting, leading to its low gas yield. Despite this disadvantage, chemical pre-treatment of water hyacinth would break up the 
complex molecules freeing up nutrients for the microbes, leading to an increase in biogas production [17, 30-32]. Ganesh et al. [34] extracted VFAs from water hyacinth using diluted cow dung. The process eliminated the indigestible fibres. Freeing up the nutrients has the possibility of increasing the biogas yields from co-digesting food waste with water hyacinth. Gunnarsson and Peterson [35] suggested longer retention times rather than expensive pre-treatment methods. In the case of water hyacinth, it is doubtful if longer retention times would free up the complex nutrients due to the complexity of its fibres.

\subsubsection{Model Kinetics}

The lag phase ranged from 0 to 14.6 hours in all tests. As explained in section 3.4 , the inoculum had already been preconditioned and starved of nutrients. This led to an immediate consumption of added substrates leading to early biogas production. The shortest T80 was by YP at 5.3 days. CP and PP were next at 6.3 and 6.8 days. The longest period was for PP at 7.4 days. The T80 period for YP and CP increased by 14 and $34 \%$, when co-digested with water hyacinth. This indicates that water hyacinth has an antagonistic effect on YP and CP that led to an increase in their retention period. The T80 results were the same for both the mono and co-digestion of CoP and PP. Since the T80 can be used as a reference for the retention time of digesters, mono digested yam and cassava peels would spend less time being digested in an anaerobic digester than when co-digested with water hyacinth. Similar to the co-digested results, the measured biogas was more than the predicted values. The respective simulated biogas values of YP, CP, CoP and PP were $94.4 \%, 92.9 \% 97.3 \%, 96.7 \%$ of their measured values.

There was a good fit of the model and gas production curves supported by $\mathrm{R}^{2}$ values of 0.9539 to 0.9749 . This confirms that the measured values are in agreement 
with the simulated values. The mono-digested results have a better fit than their codigested counterparts.

\subsubsection{Statistical analysis}

Kruskal-Wallis tests of the results showed that there was no significant difference between the groups $(\mathrm{p}>0.05)$.

\section{Conclusion}

The Niger Delta region consumes high quantities of yams, cassavas, plantains and tubers. These foods produce significant amounts of waste. This study confirms the suitability of utilizing these common food wastes as feedstock for the anaerobic digestion process. Additionally, water hyacinth may be used as a co-feedstock in the digestion process, which would help in reducing the infestation of the aquatic weed. A drawback to utilising the water hyacinth in the AD process is that it reduces the overall bioenergy yields of the feedstock by increasing the proportion of recalcitrant complex molecules, which are difficult to digest by the AD microbes. To mitigate the adverse effect of co-digesting with water hyacinth, the plant could be pre-treated to shorten its complex fibre chains, making them available for consumption by the microorganisms. Of all the samples tested, yam peel is shown to have the highest biogas potential. This food waste should be prioritised as biofuel raw material. In contrast, cassava peel has the lowest bioenergy potential due to its cyanide content, which is toxic to AD microbes. Hence it should be the last option as a biofuel if there are other alternatives. Further research is required to determine the effect of detoxifying the cassava peel on the co-digestion process. The successful implementation of anaerobic digestion as a renewable energy technology will not only provide a clean source of energy for an energy deficit region, but it will also help in mitigating environmental degradation from 
household wastes and water hyacinth infestation.

\section{References:}

1. IEA. World Energy Outlook 2013. International Energy Agency: Tokyo, Japan (2013).

2. GOPA-International Energy Consultants. The Nigerian Energy Sector 2nd ed. (2015).

3. IEG. The Welfare Impact of Rural Electrification: A Reassessment of the Costs and Benefits. (2008).

4. Thien Thu CT, Cuong PH, Hang LT, et al. Manure management practices on biogas and non-biogas pig farms in developing countries - using livestock farms in Vietnam as an example. J.Clean.Prod. 27, 64-71 (2012).

5. Teune B. The biogas programme in Vietnam; amazing results in poverty reduction and economic development. Boiling Point(53), 11-13 (2007).

6. Pham CH, Triolo JM, Thu CTT, Pedersen L, Sommer SG. Validation and recommendation of methods to measure biogas production potential. Presented at: 15th Aaap Animal Science Congress, Thailand.

7. FAOSTAT. Production/Crops World 2013. 2015(November/20) (2015).

8. Ene-Obong HN, Sanusi RA, Udenta EA, et al. Data collection and assessment of commonly consumed foods and recipes in six geo-political zones in Nigeria: Important for the development of a National Food Composition Database and Dietary Assessment. Food Chem. 140(3), 539-546 (2013).

9. NBS (National Bureau of Statistics). Consumption Pattern in Nigeria 20092010. (2012b).

10. NDDC. Niger Delta Regional Development Master Plan. (2006).

11. Drosg B, Braun R, Bochmann G, Al Saedi T. 3 - Analysis and characterisation of biogas feedstocks. In: The Biogas Handbook. Wellinger A, Murphy J, Baxter D (Eds.), Woodhead Publishing, 52-84 (2013).

12. Steffen R, Szolar O, Braun R. Feedstocks for anaerobic digestion. Institute for Agrobiotechnology Tulln, University of Agricultural Sciences, Vienna (1998).

13. Al Seadi T, Rutz D, Prassl H, et al. Biogas Handbook.-University of Southern Denmark Esbjerg (2008). 
14. Russ W, Meyer-Pittroff R. Utilizing waste products from the food production and processing industries. Crit.Rev.Food Sci.Nutr. 44(1), 57-62 (2004).

15. Campbell C, Plank C. Preparation of plant tissue for laboratory analysis. In: Handbook of reference methods for plant analysis. Kalra Y (Ed.), CRC Press, Boca Raton, 37-41 (1997).

16. Neureiter M. Maize and maize silage for biomethane production. Bioenergy Production by Anaerobic Digestion: Using Agricultural Biomass and Organic Wastes, 74 (2013).

17. Cheng J, Xie B, Zhou J, Song W, Cen K. Cogeneration of H2 and CH4 from water hyacinth by two-step anaerobic fermentation. Int J Hydrogen Energy. 35(7), 3029-3035 (2010).

18. Onyenwoke, C. A., Simonyan, KJ. Cassava post-harvest processing and storage in Nigeria: A review. African Journal of Agricultural Research. 9(53), 38533863 (2014).

19. Weis JS, Weis P. Metal uptake, transport and release by wetland plants: implications for phytoremediation and restoration. Environ.Int. 30(5), 685-700 (2004).

20. NNFCC (National Non-Food Crops Centre). Feedstocks. 2016(June/2016) (2016).

21. Deublein D, Steinhauser A. Biogas from waste and renewable resources: an introduction. John Wiley \& Sons (2011).

22. VDI 4630. VDI 4630: Fermentation of organic materials- Characterisation of the substrate, sampling, collection of material data, fermentation tests. (2006).

23. Korres, Nicholas E.,, O'Kiely, Padraig,, Benzie, John A. H.,,West, Jon,. Bioenergy production by anaerobic digestion : using agricultural biomass and organic wastes. (2013).

24. Cuzin N, Labat M. Reduction of cyanide levels during anaerobic digestion of cassava. Int.J.Food Sci.Tech. 27(3), 329-336 (1992).

25. Cuzin N, Farinet JL, Segretain C, Labat M. Methanogenic fermentation of cassava peel using a pilot plug flow digester. Bioresour.Technol. 41(3), 259-264 (1992).

26. Ubalua A. Cassava wastes: treatment options and value addition alternatives. African Journal of Biotechnology. 6(18), 2065-2073 (2007). 
27. Triolo JM, Pedersen L, Qu H, Sommer SG. Biochemical methane potential and anaerobic biodegradability of non-herbaceous and herbaceous phytomass in biogas production. Bioresour.Technol. 125, 226-232 (2012).

28. Cumbana A, Mirione E, Cliff J, Bradbury JH. Reduction of cyanide content of cassava flour in Mozambique by the wetting method. Food Chem. 101(3), 894897 (2007).

29. Bradbury JH, Denton IC. Rapid wetting method to reduce cyanogen content of cassava flour. Food Chem. 121(2), 591-594 (2010).

30. Patil J, AntonyRaj A, Gavimath C. Study on effect of pre-treatment methods on biomethanation of water hyacinth. International Journal of Advanced Biotechnology and Research. 2(1), 143-147 (2011).

31. Gao J, Chen L, Yan Z, Wang L. Effect of ionic liquid pretreatment on the composition, structure and biogas production of water hyacinth (Eichhornia crassipes). Bioresour.Technol. 132, 361-364 (2013).

32. Cheng J, Xia A, Su H, Song W, Zhou J, Cen K. Promotion of H2 production by microwave-assisted treatment of water hyacinth with dilute $\mathrm{H} 2 \mathrm{SO} 4$ through combined dark fermentation and photofermentation. Energy Conversion and Management. 73, 329-334 (2013).

33. Palmowski L, Müller J. Influence of the size reduction of organic waste on their anaerobic digestion. Water Science and Technology. 41(3), 155-162 (2000).

34. Ganesh PS, Ramasamy EV, Gajalakshmi S, Abbasi SA. Extraction of volatile fatty acids (VFAs) from water hyacinth using inexpensive contraptions, and the use of the VFAs as feed supplement in conventional biogas digesters with concomitant final disposal of water hyacinth as vermicompost. Biochem.Eng.J. 27(1), 17-23 (2005).

35. Gunnarsson CC, Petersen CM. Water hyacinths as a resource in agriculture and energy production: A literature review. Waste Manage. 27(1), 117-129 (2007). 
Table 1. Characterisation of four Niger Delta food wastes and water hyacinth.

\begin{tabular}{|c|c|c|c|c|c|}
\hline Food Waste & Water Hyacinth & Yam Peels & Cassava Peels & $\begin{array}{l}\text { Cocoyam } \\
\text { Peels }\end{array}$ & Plantain Peels \\
\hline SWI & - & 0.34 & 0.25 & 0.32 & 0.52 \\
\hline Total Solids (\%) & 7.2 & 36.6 & 29.3 & 24.5 & 15.4 \\
\hline $\begin{array}{l}\text { Volatile Solids } \\
\text { (\% TS) }\end{array}$ & 83.3 & 93.7 & 95.6 & 91.4 & 88.3 \\
\hline $\begin{array}{l}\text { Crude Protein } \\
\text { (\% VS) }\end{array}$ & 20 & 9.6 & 8.6 & 10.7 & 7.4 \\
\hline $\begin{array}{l}\text { Oil-B } \\
\text { (\% VS) }\end{array}$ & 5 & 1.2 & 24.6 & 1.8 & 4.4 \\
\hline $\begin{array}{l}\text { Nitrogen Free Extract } \\
(\% \mathrm{VS})\end{array}$ & 55 & 82.2 & 58.6 & 75.4 & 79.4 \\
\hline Ash (\% TS) & 16.7 & 6.3 & 4.4 & 8.6 & 11.7 \\
\hline
\end{tabular}

Table 2a. Kinetics of biogas production of co-digested substrates using Modified Gompertz Model (means \pm relative error)

\begin{tabular}{|c|c|c|c|c|}
\hline & YP+WH & $\mathrm{CP}+\mathrm{WH}$ & $\mathrm{CoP}+\mathrm{WH}$ & PP+WH \\
\hline $\begin{array}{lll}\text { Lag } & \text { Phase, } & \lambda \\
\text { (days) } & & \\
\end{array}$ & $0.17 \pm 0.07$ & $0.01 \pm 0.01$ & $0.14 \pm 0.03$ & 0.00 \\
\hline $\mathrm{Rm}$ (ml/g VS/day) & $82.38 \pm 1.38$ & $45.55 \pm 0.06$ & $66.73 \pm 0.42$ & $61.47 \pm 1.40$ \\
\hline$P$ (ml/g VS) & $443.65 \pm 1.27$ & $336.74 \pm 11.17$ & $426.81 \pm 10.39$ & $420.46 \pm 14.41$ \\
\hline T80 (days) & $6.0 \pm 0.00$ & $8.4 \pm 0.30$ & $6.82 \pm 0.04$ & $7.42 \pm 0.11$ \\
\hline $\mathbf{R}^{2}$ & 0.9289 & 0.9441 & 0.9476 & 0.9586 \\
\hline $\begin{array}{l}\text { Measured Biogas } \\
\text { Yield (ml/g VS) }\end{array}$ & $469.28 \pm 0.89$ & $355.61 \pm 13.13$ & $444.81 \pm 9.25$ & $439.74 \pm 14.36$ \\
\hline $\begin{array}{l}\text { Simulated Biogas } \\
\text { Yield (ml/g VS) }\end{array}$ & $443.59 \pm 1.26$ & $336.14 \pm 11.01$ & $426.55 \pm 10.35$ & $420.05 \pm 14.36$ \\
\hline$\%$ Difference & $5.48 \pm 0.09$ & $5.47 \pm 0.39$ & $4.11 \pm 0.33$ & $4.48 \pm 0.03$ \\
\hline
\end{tabular}

Table $2 \mathrm{~b}$. Kinetics of biogas production of mono-digested substrates using Modified Gompertz Model (means \pm relative error)

\begin{tabular}{|ll|lll|}
\hline \multicolumn{1}{|c|}{ YP } & CP & CoP & PP \\
\hline Lag Phase, $\lambda$ (days) & $0.61 \pm 0.08$ & 0.00 & $0.30 \pm 0.01$ & 0.00 \\
\hline $\mathbf{R m ~ ( m l / g ~ V S / d a y ) ~}$ & $135.3 \pm 2.12$ & $87.91 \pm 0.51$ & $68.73 \pm 3.13$ & $62.96 \pm 1.26$ \\
\hline $\mathbf{P}$ (ml/g VS) & $586.76 \pm 20.93$ & $406.36 \pm 5.44$ & $459.33 \pm 7.04$ & $454.68 \pm 6.70$ \\
\hline T80 (days) & $5.25 \pm 0.05$ & $6.25 \pm 0.05$ & $6.84 \pm 0.17$ & 7.44 \\
\hline $\mathbf{R}^{2}$ & 0.9539 & 0.9704 & 0.9749 & 0.9702 \\
\hline $\mathbf{R}^{2}$ Adj. & 0.9394 & 0.9605 & 0.9666 & 0.9603 \\
\hline RMSE & $0.2023 \pm 0.01$ & 0.2268 & 0.0773 & $0.1234 \pm 0.01$ \\
\hline $\begin{array}{l}\text { Measured Biogas } \\
\text { Yield (ml/g VS) }\end{array}$ & $621.42 \pm 20.58$ & $437.35 \pm 5.37$ & $471.66 \pm 7.46$ & $469.57 \pm 7.76$ \\
\hline $\begin{array}{l}\text { Simulated Biogas } \\
\text { Yield (ml/g VS) }\end{array}$ & $586.76 \pm 20.93$ & $406.35 \pm 5.44$ & $458.90 \pm 7.14$ & $454.02 \pm 6.72$ \\
\hline$\%$ Difference & $5.59 \pm 0.24$ & $7.09 \pm 0.10$ & $2.70 \pm 0.03$ & $3.31 \pm 0.17$ \\
\hline
\end{tabular}


Figure 1. Daily and cumulative biogas production curves of co-digested food waste (means with error bars indicating duplicate values).

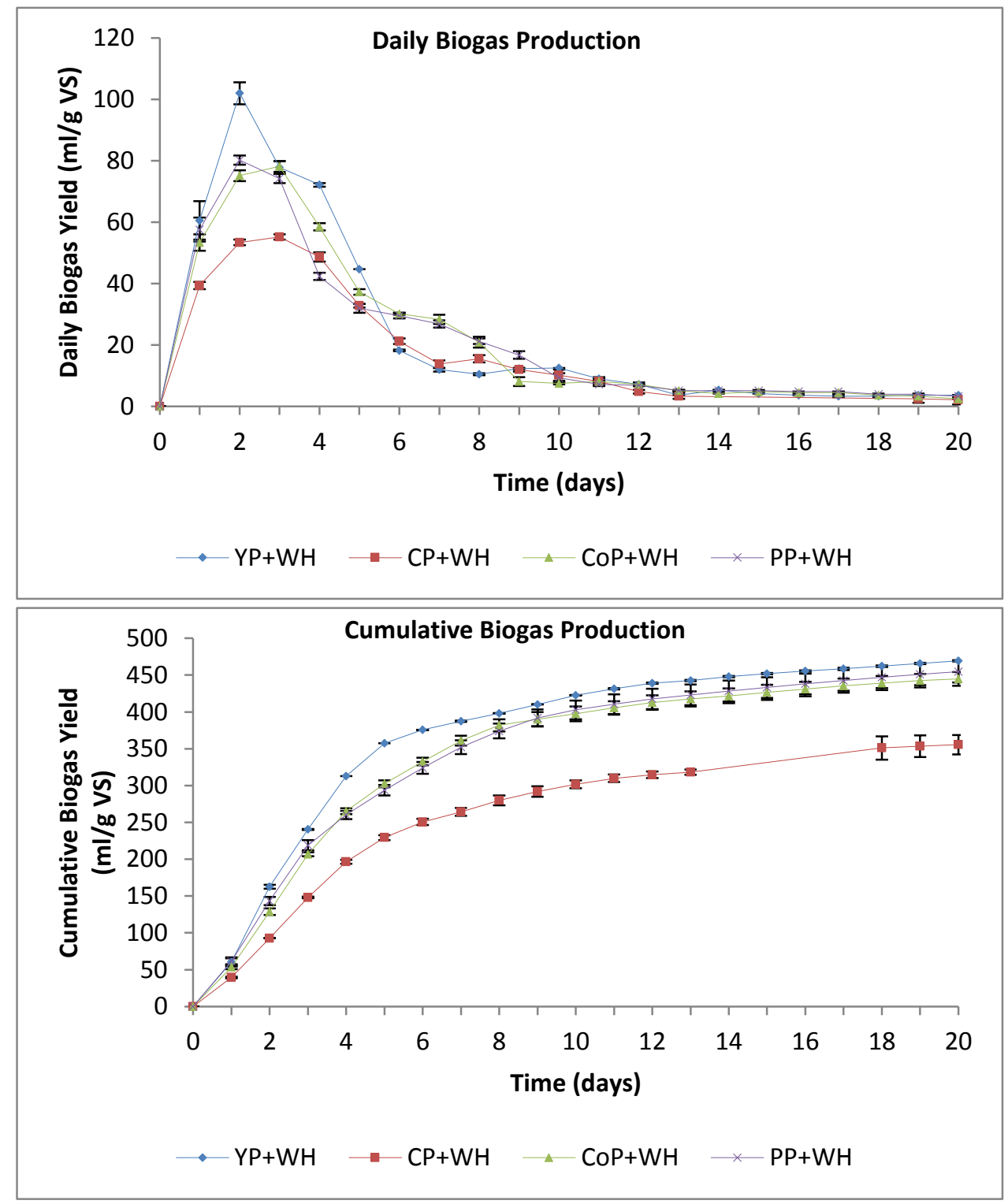


Figure 2. Biogas composition of co-digested food waste (max propane measuring limit at $5 \%$ ).

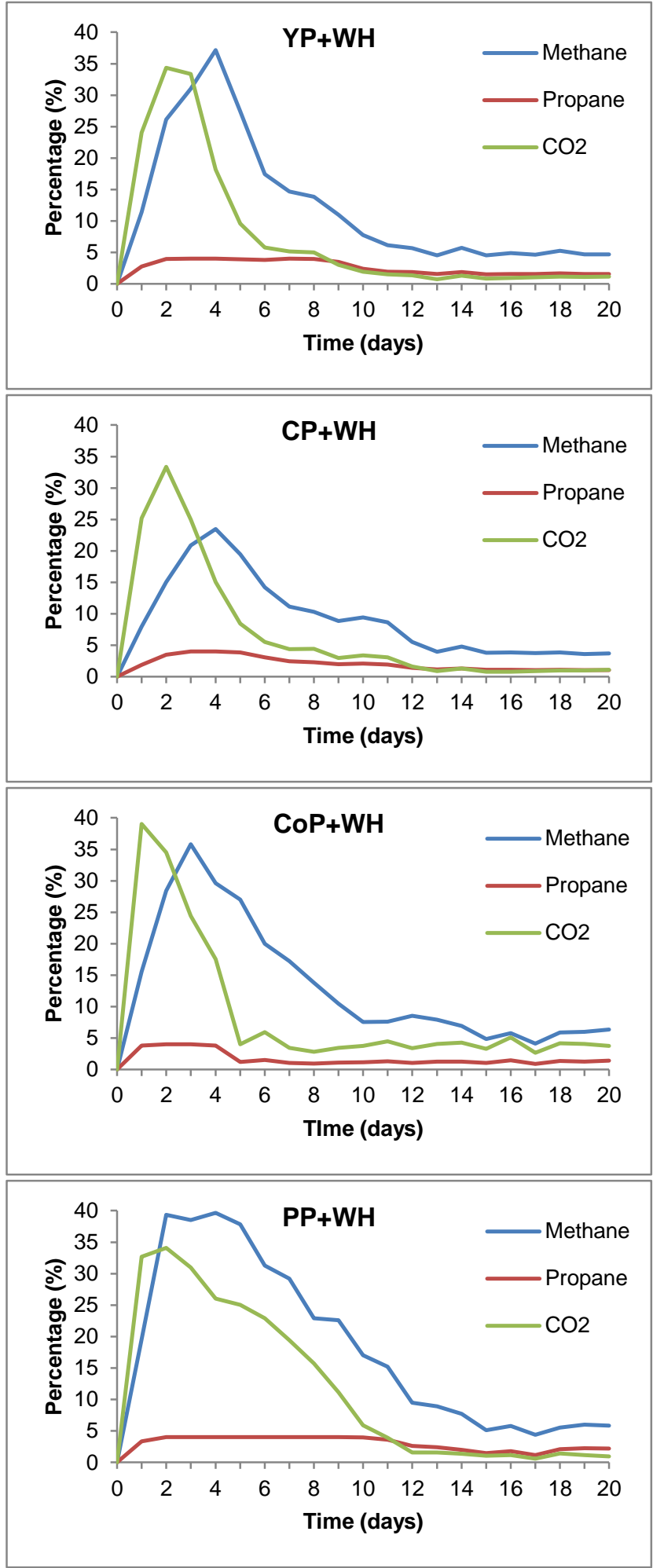


Figure 3. Daily and cumulative biogas production curves of mono-digested food waste (means with error bars indicating duplicate values).
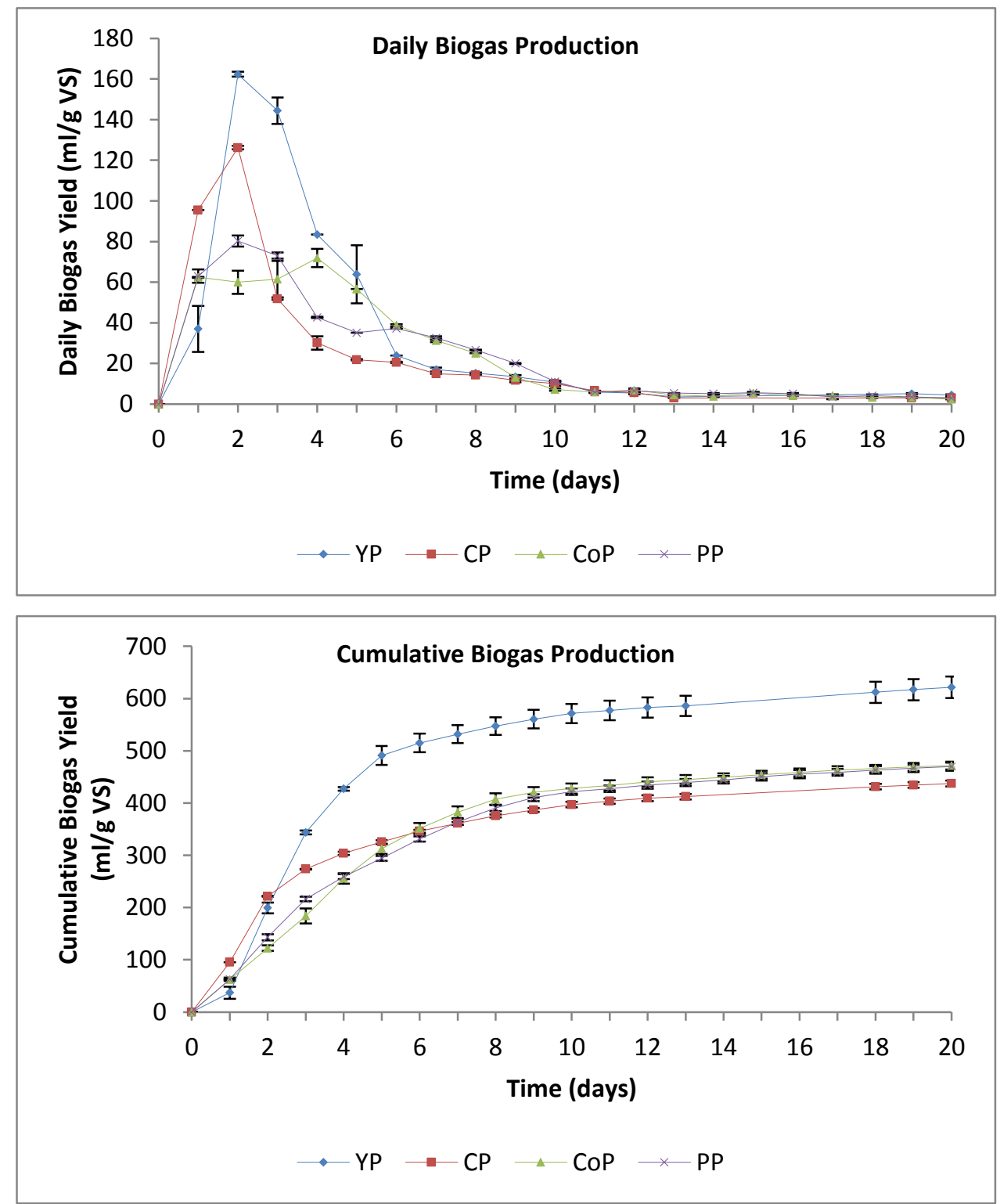

hyacinth.

Table 1. Characterisation of four Niger Delta food wastes and water hyacinth.

\begin{tabular}{|lccccc|}
\hline Food Waste & Water Hyacinth & Yam Peels & Cassava Peels & $\begin{array}{l}\text { Cocoyam } \\
\text { Peels }\end{array}$ & Plantain Peels \\
\hline SWI & - & 0.34 & 0.25 & 0.32 & 0.52 \\
\hline Total Solids (\%) & 7.2 & 36.6 & 29.3 & 24.5 & 15.4 \\
\hline $\begin{array}{l}\text { Volatile Solids } \\
\text { (\% TS) }\end{array}$ & 83.3 & 93.7 & 95.6 & 91.4 & 88.3 \\
\hline $\begin{array}{l}\text { Crude Protein } \\
\text { (\% VS) }\end{array}$ & 20 & 9.6 & 8.6 & 10.7 & 7.4 \\
\hline Crude Fibre (\% VS) & 20 & 7.0 & 8.2 & 12.1 & 8.8 \\
\hline $\begin{array}{l}\text { Oil-B } \\
\text { \% VS) }\end{array}$ & 5 & 1.2 & 24.6 & 1.8 & 4.4 \\
\hline $\begin{array}{l}\text { Nitrogen Free Extract } \\
\text { (\% VS) }\end{array}$ & 55 & 82.2 & 58.6 & 75.4 & 79.4 \\
\hline Ash (\% TS) & 16.7 & 6.3 & 4.4 & 8.6 & 11.7 \\
\hline Moisture (\%) & 92.8 & 63.4 & 70.7 & 75.5 & 84.6 \\
\hline
\end{tabular}


Table 2a. Kinetics of biogas production of co-digested substrates using Modified

Gompertz Model (means \pm relative error)

\begin{tabular}{|lc|ccc|}
\hline & $\mathbf{Y P + W H}$ & $\mathbf{C P}+\mathbf{W H}$ & $\mathbf{C o P}+\mathbf{W H}$ & $\mathbf{P P + W H}$ \\
\hline $\begin{array}{l}\text { Lag Phase, } \boldsymbol{\lambda} \\
\text { (days) }\end{array}$ & $0.17 \pm 0.07$ & $0.01 \pm 0.01$ & $0.14 \pm 0.03$ & 0.00 \\
\hline $\mathbf{R m}$ (ml/g VS/day) & $82.38 \pm 1.38$ & $45.55 \pm 0.06$ & $66.73 \pm 0.42$ & $61.47 \pm 1.40$ \\
\hline $\mathbf{P}$ (ml/g VS) & $443.65 \pm 1.27$ & $336.74 \pm 11.17$ & $426.81 \pm 10.39$ & $420.46 \pm 14.41$ \\
\hline T80 (days) & $6.0 \pm 0.00$ & $8.4 \pm 0.30$ & $6.82 \pm 0.04$ & $7.42 \pm 0.11$ \\
\hline $\mathbf{R}^{2}$ & 0.9289 & 0.9441 & 0.9476 & 0.9586 \\
\hline $\mathbf{R}^{2}$ Adj. & 0.9051 & 0.9255 & 0.9302 & 0.9449 \\
\hline RMSE & 0.1584 & $0.1344 \pm 0.01$ & 0.1120 & $0.1339 \pm 0.01$ \\
\hline $\begin{array}{l}\text { Measured Biogas } \\
\text { Yield (ml/g VS) }\end{array}$ & $469.28 \pm 0.89$ & $355.61 \pm 13.13$ & $444.81 \pm 9.25$ & $439.74 \pm 14.36$ \\
\hline $\begin{array}{l}\text { Simulated Biogas } \\
\text { Yield (ml/g VS) }\end{array}$ & $443.59 \pm 1.26$ & $336.14 \pm 11.01$ & $426.55 \pm 10.35$ & $420.05 \pm 14.36$ \\
\hline$\%$ Difference & $5.48 \pm 0.09$ & $5.47 \pm 0.39$ & $4.11 \pm 0.33$ & $4.48 \pm 0.03$ \\
\hline
\end{tabular}


Table $2 \mathrm{~b}$. Kinetics of biogas production of mono-digested substrates using Modified

Gompertz Model (means \pm relative error)

\begin{tabular}{|lcccc|}
\hline & YP & CP & CoP & PP \\
\hline Lag Phase, $\boldsymbol{\lambda}$ (days) & $0.61 \pm 0.08$ & 0.00 & $0.30 \pm 0.01$ & 0.00 \\
\hline Rm (ml/g VS/day) & $135.3 \pm 2.12$ & $87.91 \pm 0.51$ & $68.73 \pm 3.13$ & $62.96 \pm 1.26$ \\
\hline $\mathbf{P}$ (ml/g VS) & $586.76 \pm 20.93$ & $406.36 \pm 5.44$ & $459.33 \pm 7.04$ & $454.68 \pm 6.70$ \\
\hline T80 (days) & $5.25 \pm 0.05$ & $6.25 \pm 0.05$ & $6.84 \pm 0.17$ & 7.44 \\
\hline $\mathbf{R}^{2}$ & 0.9539 & 0.9704 & 0.9749 & 0.9702 \\
\hline $\mathbf{R}^{2}$ Adj. & 0.9394 & 0.9605 & 0.9666 & 0.9603 \\
\hline RMSE & $0.2023 \pm 0.01$ & 0.2268 & 0.0773 & $0.1234 \pm 0.01$ \\
\hline $\begin{array}{l}\text { Measured Biogas } \\
\text { Yield (ml/g VS) }\end{array}$ & $621.42 \pm 20.58$ & $437.35 \pm 5.37$ & $471.66 \pm 7.46$ & $469.57 \pm 7.76$ \\
\hline $\begin{array}{l}\text { Simulated Biogas } \\
\text { Yield (ml/g VS) }\end{array}$ & $586.76 \pm 20.93$ & $406.35 \pm 5.44$ & $458.90 \pm 7.14$ & $454.02 \pm 6.72$ \\
\hline \% Difference & $5.59 \pm 0.24$ & $7.09 \pm 0.10$ & $2.70 \pm 0.03$ & $3.31 \pm 0.17$ \\
\hline
\end{tabular}


Figure 1. Daily and cumulative biogas production curves of co-digested food waste (means with error bars indicating duplicate values).

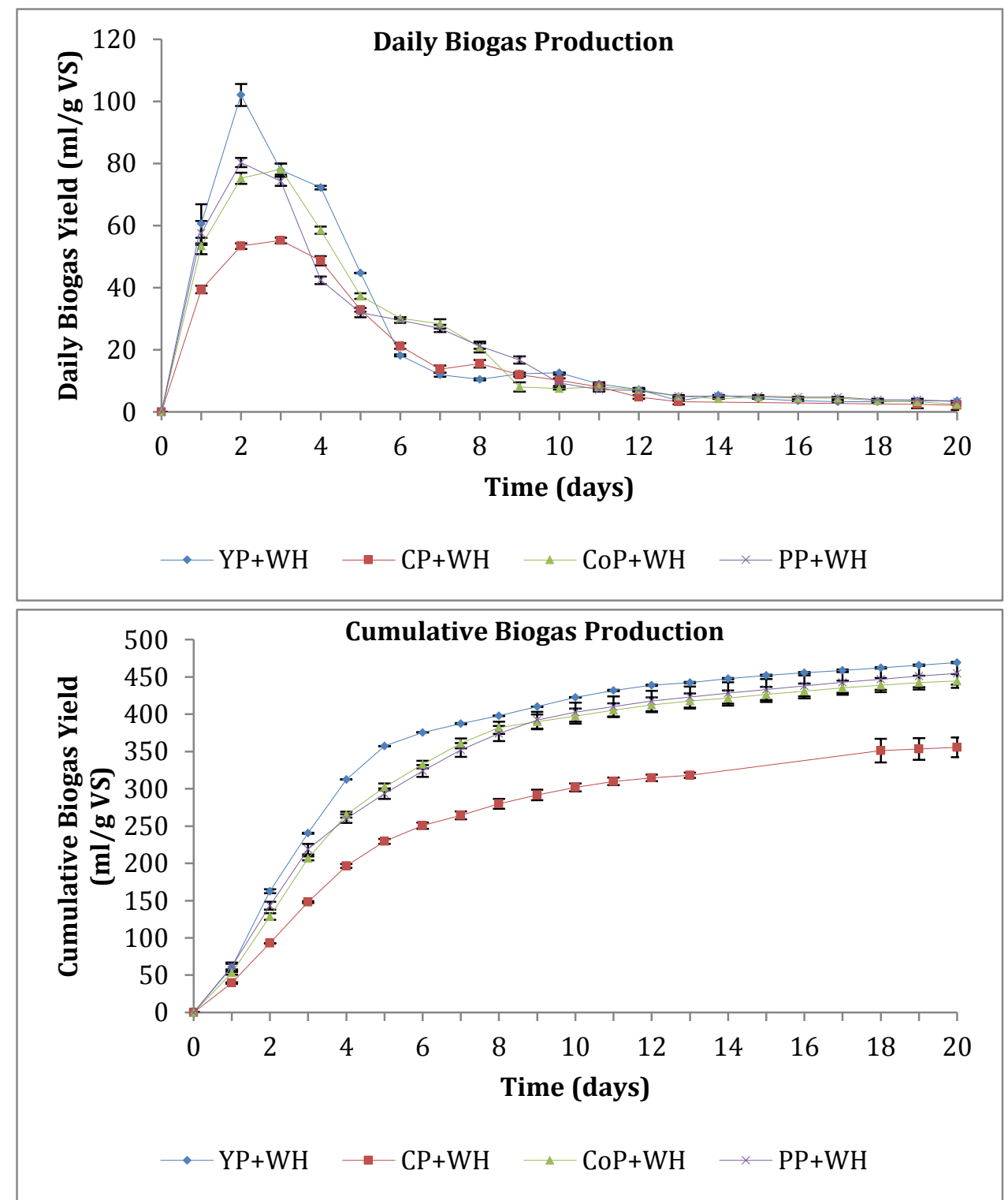


Figure 2. Biogas composition of co-digested food waste (max propane measuring limit at $5 \%$ ).

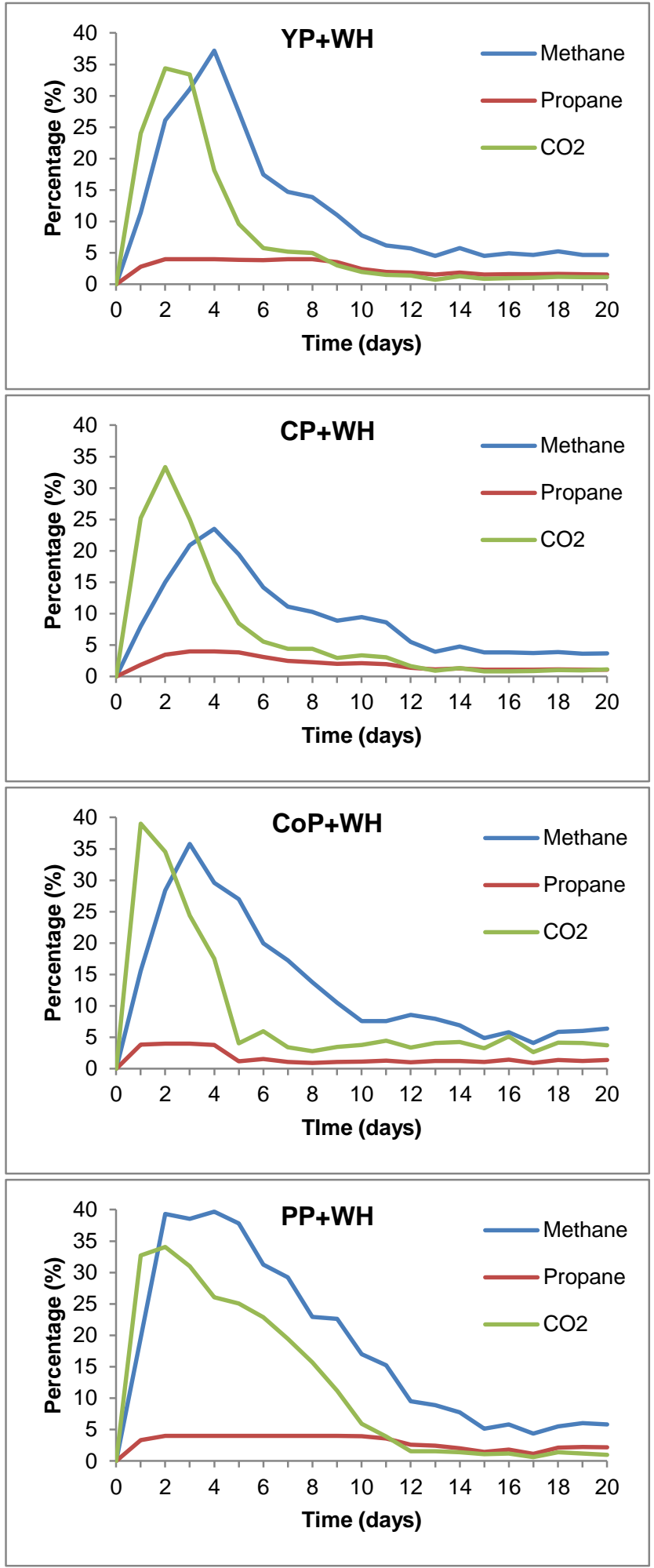


Figure 3. Daily and cumulative biogas production curves of mono-digested food waste (means with error bars indicating duplicate values).
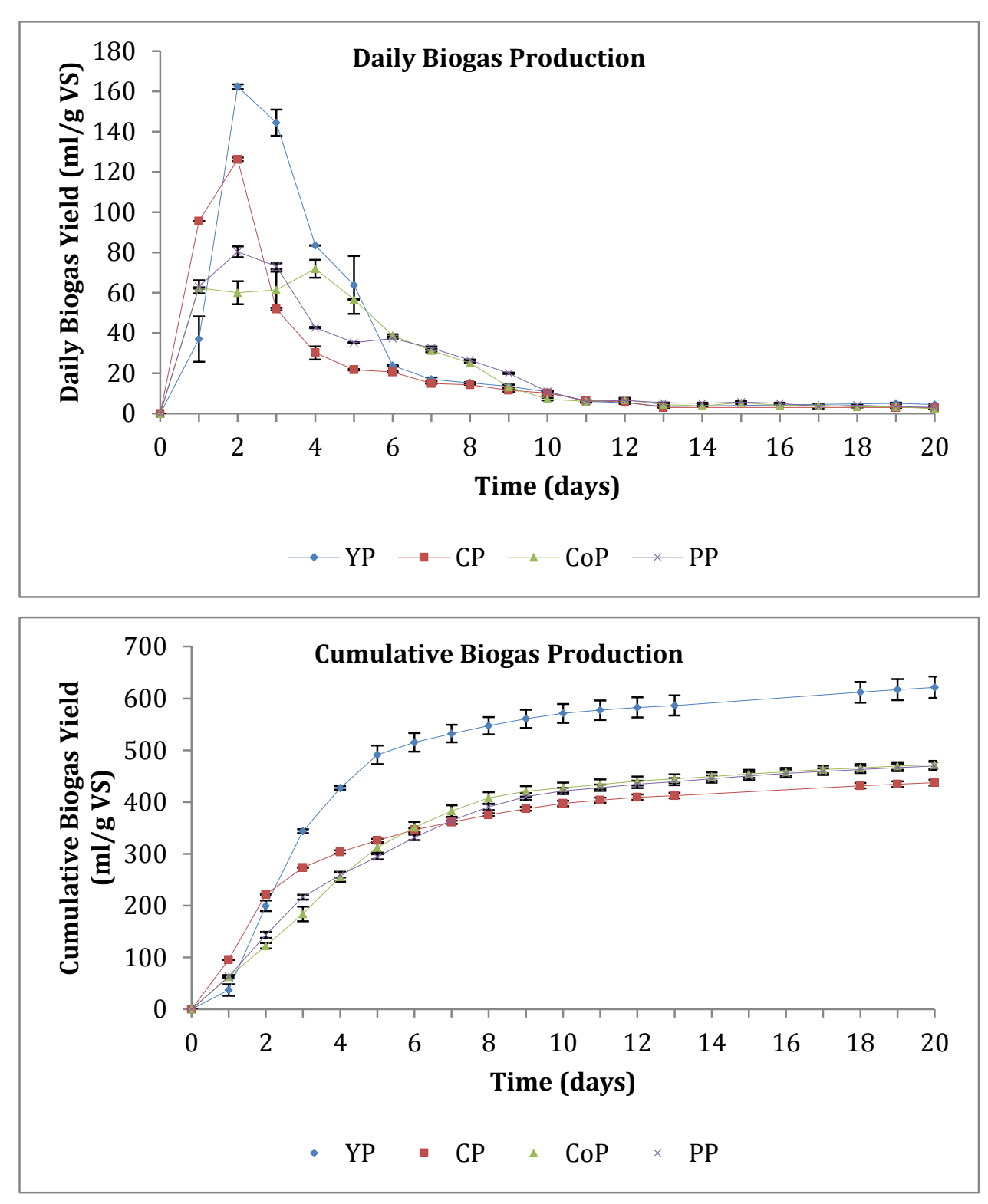


\section{List of Main Changes}

1. The last five paragraphs of Section 3.2 have been reduced to two short paragraphs containing only the most important features of the section.

2. I have included a clarification in the experimental methods on why the $\mathrm{C} / \mathrm{N}$ wasn't used in the experimental method.

3. I have provided the botanical names with authority of Yam, Cassava, Cocoyam and Plantain.

4. The manuscript has been justified aligned.

5. An addition has been made to the Conclusion section of the paper for further research on the effects of pre-treatment on the biogas production of co-digestion cassava peel. 